\title{
The Haidbach deposit in the Central Tauern Window, Eastern Alps, Austria: a metamorphosed orthomagmatic Ni-Cu-Co-PGE mineralization in the Polymetallic Ore District Venediger Nappe System - Hollersbach Complex
}

\author{
Frank Melcher ${ }^{1 *}$, Sonja Schwabl ${ }^{2}$, Peter Onuk ${ }^{1}$, Thomas Meisel ${ }^{3}$, Thomas Aiglsperger ${ }^{4}$, Joaquín A. Proenza ${ }^{5}$ \\ 1) Chair of Geology and Economic Geology, Montanuniversität Leoben, Peter-Tunnerstrasse 5, 8700 Leoben, Austria; frank.melcher@unileoben.ac.at, \\ ORCID: 0000-0001-8654-0793; peter.onuk@unileoben.ac.at, ORCID: 0000-0003-3270-0872; \\ 2) Urtelgasse 4, 2620 Neunkirchen, Austria; sonja.schwabl@gmx.at, \\ 3) Chair of General and Analytical Chemistry, Montanuniversität Leoben, Franz-Josefstrasse 18, 8700 Leoben, Austria; thomas.meisel@unileoben.ac.at, OR- \\ CID: 0000-0001-5572-3212 \\ 4) Department of Civil Engineering and Natural Resources, Luleå University of Technology, SE 97187 Luleå, Sweden; thomas.aiglsperger@gmail.com, \\ ORCID: 0000-0002-1298-0320 \\ 5) Departament de Mineralogia, Petrologia i Geologia Aplicada, Facultat de Ciènces de la Terra, Universitat de Barcelona, C/Marti i Franquès, s/n, 08028, \\ Barcelona, Spain; japroenza@ub.edu, ORCID: 0000-0001-8738-7305 \\ *) Corresponding author
}

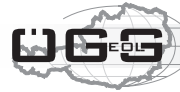

KEYWORDS

Nickel-copper sulfide ore, platinum-group minerals, rhenium sulfide, Hollersbach Complex, orthomagmatic sulfide deposit

\begin{abstract}
Cu-Ni-Co-PGE mineralization occurs at Haidbachgraben in the Early Palaeozoic, Subpenninic Hollersbach Complex of the Central Tauern Window, Austria. Massive sulfide ore formed from sulfide melt segregated from silicate melt during intrusion of pyroxenite into magmatic rocks formed in an MORB-type environment. Relics of magmatic minerals include chromian spinel and polyphase sulfide droplets composed of pyrrhotite, chalcopyrite and pentlandite preserved in recrystallized pyrite. Both ore and host rocks were multiply deformed and metamorphosed, leading to hornblendite carrying the ore, enveloped by chlorite-epidote schist. Conditions of - likely Variscan - amphibolite facies metamorphism are documented by relict pargasitic cores in hornblende and actinolite-tremolite, and by ternary sulfarsenide compositions in the Co-Ni-Fe solid solution series that are the most common accessory minerals found in the sulfide ore. Pyrrhotite, pentlandite, chalcopyrite and pyrite are the major sulfide minerals. Chalcopyrite is $\mathrm{Cd}$-rich and retains a high-temperature magmatic signature. High $\mathrm{Co} / \mathrm{Sb}$ and moderate $\mathrm{Se} / \mathrm{As}$ ratios in pyrite also point to a magmatic environment of mineralization. The accessory mineral assemblage of small grain size (mostly $<10 \mu \mathrm{m})$ comprises native Au-Ag alloy and petzite as Au-Ag minerals, sperrylite, a variety of Pd tellurides and bismuthotellurides with elevated $\mathrm{Sb}$, irarsite, and Re sulfides such as tarkianite and a Pb-Re sulfide. In addition, minor molybdenite, bournonite, scheelite and selenides have been identified. Two precious metal assemblages are present in individual samples: (1) hessite associated with Pd tellurides, often accompanied by sphalerite and chalcopyrite; (2) tarkianite forming euhedral inclusions in pyrite. Sperrylite and Au-Ag native alloys are present throughout and were also detected in silicate matrix. Most of the precious metal-bearing phases must have formed during recrystallization of base metal sulfides after the magmatic, and probably during later metamorphic events terminating in the Neoalpine Tauern crystallization.
\end{abstract}

\section{Introduction}

Metamorphosed Palaeozoic rocks in the Central Tauern Window, Eastern Alps, host various ore types, including Ni-Cu sulfides, Cu-bearing pyrite ores, vein-type $\mathrm{Pb}$-Zn-fluorite ores and stockwork-type scheelite ores. Elevated Pt (up to $0.6 \mathrm{mg} / \mathrm{kg}$ ) and Pd concentrations (up to $0.22 \mathrm{mg} / \mathrm{kg}$ ) have been reported from $\mathrm{Ni}$-Cu sulfide samples collected at the former Haidbach mine in Salzburg, Austria (Paar, 1994; Weber et al., 1997; Schedl et al., 2001). This mineralization, also known as "Haibach", "Schlaggraben" and "Gaiswand" is considered a member of the "Polymetallic ore district Venediger nappe system - Hollersbach Complex" (Weber and Lipiarski, 2020), which is an important ore district in the Subpenninic Nappe System (Fig. 1). The elevated Pt and
Pd concentrations prompted a re-evalution of the deposit including mapping of still accessible underground exposures and sample collection for geochemical and mineralogical investigation. The first platinum-group minerals (PGM) at Haidbach were found in samples recovered in 2013, and subsequent systematic sampling revealed a large number, albeit of small grain size (usually $<10 \mu \mathrm{m}$ ), of rare phases carrying Pd, Pt, Ir, Re, Au and Ag (Schwabl, 2016; Schwabl et al., 2015, 2016). Heavy mineral concentrates from the most massive ore types were produced using the hydroseparation method (Rudashevsky et al., 2001; Rudashevsky et al., 2002) in order to find larger PGM and Re sulfide grains more suitable for scanning electron microscope and electron microprobe studies (Melcher et al., 2017, 2019). 


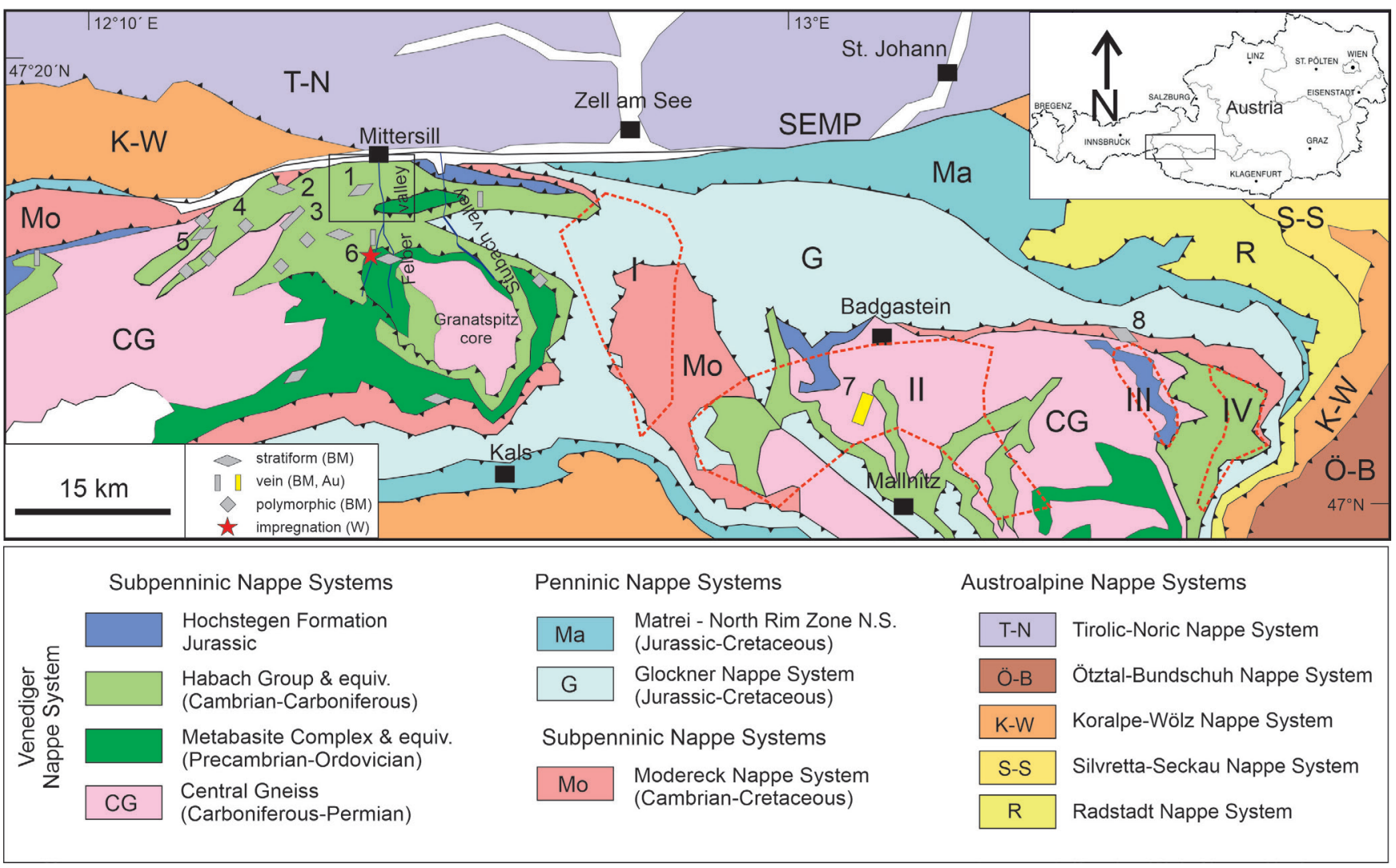

Figure 1. Geological overview of the central and eastern Tauern Window, Austria, modified from IRIS Online (Weber and Lipiarski, 2020). Base metal (BM) mineralizations in Palaeozoic rocks of the Venediger Nappe System are highlighted by grey, others by coloured symbols. Numbered deposits mentioned in the text: 1: Haidbach Cu-Ni-(Co-PGE) deposit; 2: Brenntal Cu-pyrite deposit; 3: Achselalpe/Flecktrogalm Zn-Pb-fluorite deposit; 4: Peitingalm Cu-Au-Ag deposit; 5: Hochfeld Cu deposit; 6: Felbertal scheelite deposit; 7: Radhausberg Au deposit; 8: Sprinzgasse Cu-Zn-Au deposit. Tauern gold districts are marked by stippled red lines and numbered as follows: I: Gold ore district Glockner Nappe System (Hirzbach-Schiedalpe-Kloben); II: Gold ore district Venediger Nappe System (Rauris-Gastein Tauern gold veins); III: Gold-(arsenic) ore district Venediger Nappe System - Silbereck Formation (Rotgülden-Schurfspitze); IV: Gold-(tungsten) ore district Venediger Nappe System - Storz-Kareck Complex (Schellgaden). SEMP: Salzach-Ennstal-Mariazell-Puchberg fault. Black square encircles study area of Figure 2.

The Eastern Alps have not been considered a target for magmatic Ni-Cu-platinum-group element (PGE) deposits, and PGM have rarely been documented. Exceptions have been reported from Late Proterozoic chromitite in Styria (Thalhammer and Stumpfl, 1988; Thalhammer et al., 1990; Melcher and Mali, 1998; Malitch et al., 2001, 2003a, 2003b) and from chromitite and Ni sulfide ores in the Ivrea Verbano Zone of northern Italy (e.g., Ferrario and Garuti, 1990; Zaccarini et al., 2014). In addition, sperrylite has been documented from alluvial material in the Turtmann valley, Switzerland (Stalder et al., 1998). Detrital PGM have also been described from rivers draining the Alps, such as the Rhine (Oberthür et al., 2016), Danube (Dill et al., 2009) and Durance rivers (Johan et al., 1990). However, the sources of these unusual PGM assemblages remain unclear. This study describes the mineralogy and geochemistry of the Ni-Cu-Co-PGE sulfide-arsenide-telluride assemblage discovered at Haidbach. Furthermore, we discuss its genesis in the frame of the complex metallogenetic history of Palaeozoic units within the Subpenninic Nappe System.

\section{Geological setting and mine history}

Host rocks of the Haidbach ore are part of the pre-Mesozoic Subpenninic Nappe System of the Venediger Duplex in the Tauern Window of the Eastern Alps (Fig. 1; Schmid et al., 2013). In the Subpenninic units, the Venediger Nappe System forms the tectonically lower units, followed by the Modereck Nappe System. Both are overthrust by the Lower (Glockner and Rauris Nappes) and Upper Penninic Nappes (Matrei-Northern Marginal Zone Nappe System). The Venediger Nappe System is subdivided into the footwall Granatspitz Nappe including the Zwölferzug, the Zillertal Nappes with the Riffl-Tauernkogel, Pihapper and Felber units, and the hangingwall Tux Nappe. The Haidbach mineralization is attributed to the Pihapper unit of the Zillertal Nappe (Heinisch et al., 2003). The orebody is hosted by prasinite (mainly chlorite schist) of what was previously termed the "Habach Series" (Frasl, 1958; Heinisch et al., 2015). According to a redefinition based on geochronological results, the Habach Series was split into the Cambrian to Lower Ordovician Metabasite Complex and the Upper Devonian to Upper Carboniferous Habach Group (Pestal 
et al., 2009; Heinisch et al., 2015). The Metabasite Complex consists of a metamorphosed ophiolitic sequence including amphibolite, gabbro-amphibolite, hornblendite and prasinite representing oceanic crust formed 540 to $480 \mathrm{Ma}$ ago. This metaophiolite is now assigned to the Hollersbach Complex. The Habach Group s.s. comprises a series of metamorphosed calc-alkaline volcanic rocks formed along an active continental margin or island arc 370 to $300 \mathrm{Ma}$ ago, as well as associated "Habach" phyllites; these rocks are now referred to as Peitingalm Complex (Heinisch et al., 2015). Some of the Early Palaeozoic rocks were intruded by granitoids during the Variscan orogenic event (ca. 340-270 Ma), and all Subpenninic units were metamorphosed at least twice during the Variscan (greenschist to lower amphibolite facies) and Late Alpine orogenic events reaching greenschist facies conditions in the study area (ca. $450^{\circ} \mathrm{C}$ : Schuster et al., 2004; Groß et al., 2020). Variscan granitoids are considered responsible for enrichment of W, Mo, Be and Sn in the Central Tauern Window (Niedermayr and Schroll, 1983).

The Palaeozoic metavolcanic and metasedimentary rocks of the Hollersbach and Peitingalm Complexes are host to a number of metal accumulations representing various ore types (Fig. 1; Appendix 1). In addition to the Haidbach deposit that is classified as "stratiform $\mathrm{Ni}-\mathrm{Cu}$ " in IRIS Online (Weber and Lipiarski, 2020), the "Polymetallic ore district Venediger Nappe System - Hollersbach
Complex" comprises vein-hosted Zn-Pb-fluorite (e.g., Achselalpe), and a total of 39 small and medium-sized stratiform Cu-pyrite \pm Au deposits (e.g., Mühlbachtal/ Brenntal, Hochfeld, Bärnbad; Fig. 1). In the Habach valley of the Central Tauern Window, the polymetallic Peitingalm deposit (Fig. 1) hosted by Habach phyllites is regarded as a member of the "Schellgaden-type Au-W ores" (Paar, 2000) and attributed to the "Polymetallic ore district Venediger nappe - Peitingalm Complex" with a total of 6 deposits. This unit also hosts the stratiform Hochfeld Cu mineralization in the Untersulzbach valley that was mined until 1953 and since 1993 hosts a show mine (Fig. 1; Lerch et al., 2009). The former Sprinzgasse mine in the Eastern Tauern Window is a polymetallic stratiform deposit hosted by Palaeozoic metasediments and volcanogenic rocks of the Murtörl Series, an equivalent of the Habach Group now located in the overlying Modereck Nappe System (Fig. 1). The stockwork-type scheelite deposit at Felbertal, located just $5.2 \mathrm{~km}$ south of the Haidbach location, is related to Variscan granite intrusion into mafic rocks of the Lower Magmatic Suite of Early Palaeozoic age (amphibolite, hornblendite and orthogneiss; Fig. 1). From the Felbertal scheelite deposit, 0.5 million tonnes of ore are produced annually from stockwork-type and disseminated mineralization in amphibolite and gneisses. Radiometric data of the scheelite mineralization and its immediate host rocks indicate an age of ca. 340 Ma for the granitoids (Kozlik et

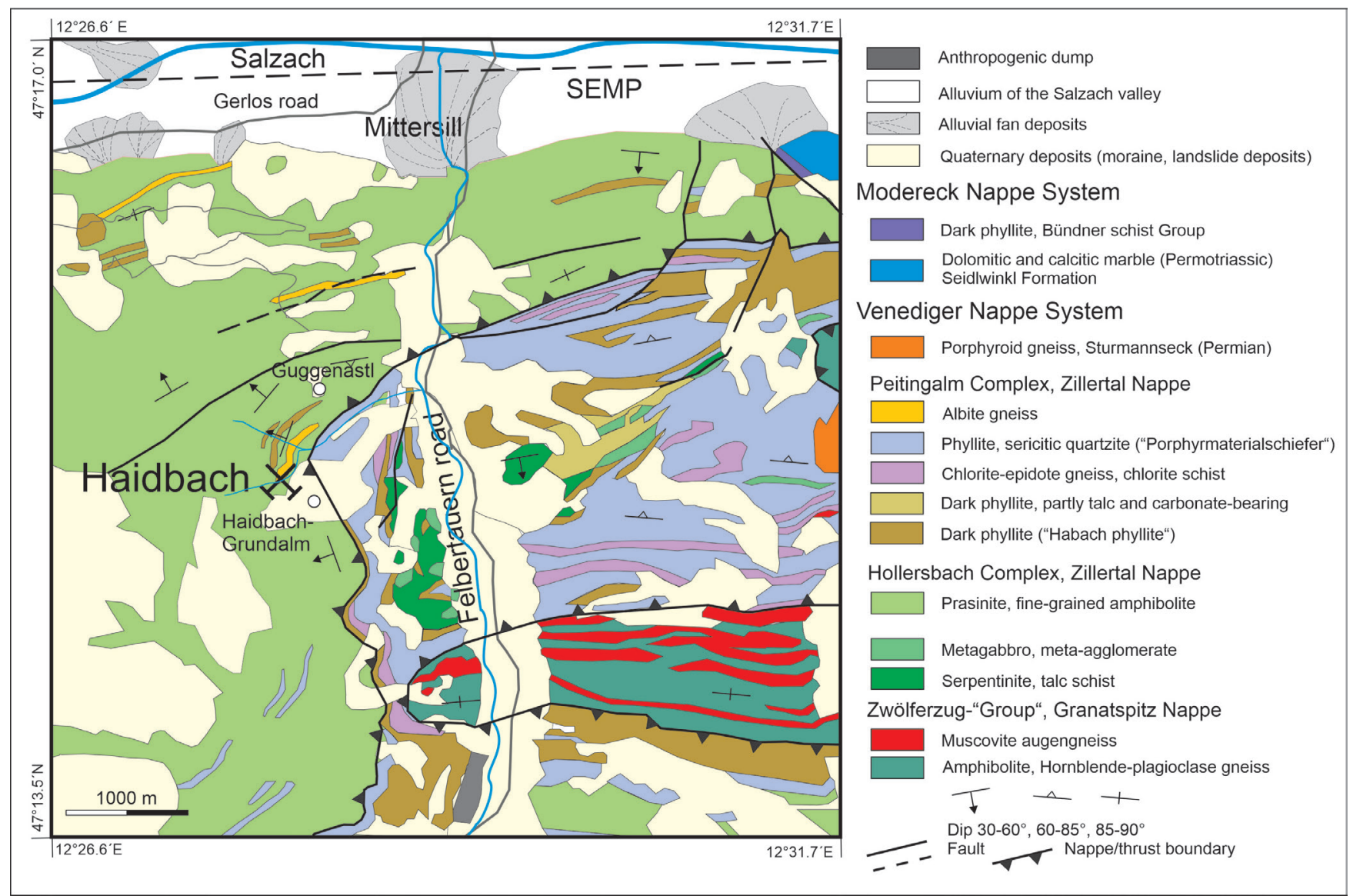

Figure 2. Geological map of the study area illustrating the location of the Haidbach deposit in the central part of the northern Tauern Window, modified from Heinisch et al. $(2003,2015)$ and Frank et al. (1987). 
al., 2016a, b) and the ore (scheelite, $319 \pm 34$ Ma Sm-Nd age: Eichhorn et al., 1997; Raith et al., 2011; Re-Os ages of molybdenite: 358-336 Ma; Raith and Stein, 2006). Mesothermal sulfide-rich polymetallic vein deposits crosscutting basement and Mesozoic cover rocks in the central and eastern Tauern Window, including the "Gold ore district Venediger nappe system - Rauris-Gastein Tauern gold veins" with 92 occurrences listed in IRIS Online, are of Neogene age (ca. $27 \mathrm{Ma}$ ). In Medieval times, the most important mining areas were active at Radhausberg/ Gastein and at Hoher Goldberg/Rauris (Paar, 1994, 2000; Fig. 1).

The Haidbach mine is located at 1400 metre above sea level in the steep slopes west of the Felber valley south of Mittersill (Figs. 1, 2). According to the geological map (Fig. 2), it is situated in the hanging wall of a tectonic boundary between the (younger) Peitingalm Complex in the tectonic footwall and the (older) Hollersbach Complex above. Along the thrust, the Peitingalm Complex consists of light sericitic phyllite locally termed "porphyry material schist" (Frasl, 1958) associated with chlorite schist and dark phyllite (Fig. 2). Serpentinite and metagabbro crop out along the western and eastern flanks of the outermost Felber valley (Fig. 2). In the area of the Haidbach mine, prasinite, dark phyllite and a layer of albite gneiss have been mapped and assigned to the Hollersbach Complex (Fig. 2). However, the tectonic situation is complicated by thrusting and faulting and therefore a clear assignment to either of the lithostratigraphic and tectonic units is problematic. The presence, in the underground exposures, of light albite-rich rock having calc-alkaline composition could also be taken as an argument for correlation with the Peitingalm Complex.

Mining activities at Haidbach were first mentioned in 1795, but the deposit was in operation much earlier based on the recent discovery of a hand-made adit (Schrämstollen) near the entrance of the Peterstollen that explores the upper mine level (Seifriedsberger, 2015). During exploration activities from 1910-1915 and
1938-1939, 545 meters of mine adits were produced (Seifriedsberger, 2015; for a detailed account on exploration activities) that outlined a lens-shaped ore body of $30 \times 45 \times 15$ metre size (Paar, 1994). Historically, several tons of manually pre-enriched ore were processed by the Krupp company in Germany. Results were promising, but the remoteness and difficult access prevented further activities, and the works were abandoned after 1945. Ore reserves have been estimated at 18,000 tons grading $1.15 \%(\mathrm{~m} / \mathrm{m}) \mathrm{Ni}, 1.95 \%(\mathrm{~m} / \mathrm{m}) \mathrm{Cu}$ and $0.15 \%(\mathrm{~m} / \mathrm{m})$ Co (Reitsch, 1911), and after subsequent re-evaluation at $10,000-15,000$ tonnes grading $0.76 \%(\mathrm{~m} / \mathrm{m}) \mathrm{Cu}$ and 0.86 $\%(\mathrm{~m} / \mathrm{m}) \mathrm{Ni}$ (Aigner, 1938), respectively.

\section{Methods of investigation}

Mine adits were mapped and systematically sampled. Sample numbers mentioned in this contribution are from the following locations: (1) Peterstollen, upper level of the mine, sulfide ore (sample numbers HB3, P13, P27, $\mathrm{P} 28)$, host rock (HB5); (2) middle level of the mine, sulfide ore (P12, P25, HB9), host rock (P22); (3) lower level, sulfide ore (P3, P9); (4) additional host rock samples comprising chlorite schist (P15) and amphibolite (P17, P18, P19) were collected along the foot path connecting the mine site with the locality Guggenastl (Fig. 2).

Rocks and minerals were investigated in thin and polished sections using transmitted and reflected light microscopy and scanning electron microanalysis (SEM). Most mineral compositions were determined using a ZEISS $^{\circledR}$ EVO MA 10 SEM equipped with a tungsten filament and a Bruker XFlash ${ }^{\circledR}$ energy-dispersive (EDX) detector. Additional compositional data were acquired by wavelength-dispersive spectrometry using a JEOL JXA 8200 electron microprobe (E.F. Stumpfl electron microprobe laboratory in Leoben) equipped with a tungsten filament. High-resolution back scatter electron (BSE) images and EDX measurements were obtained using a field emission gun (FEG) JEOL Hyperprobe at the Natural History Museum, Vienna.
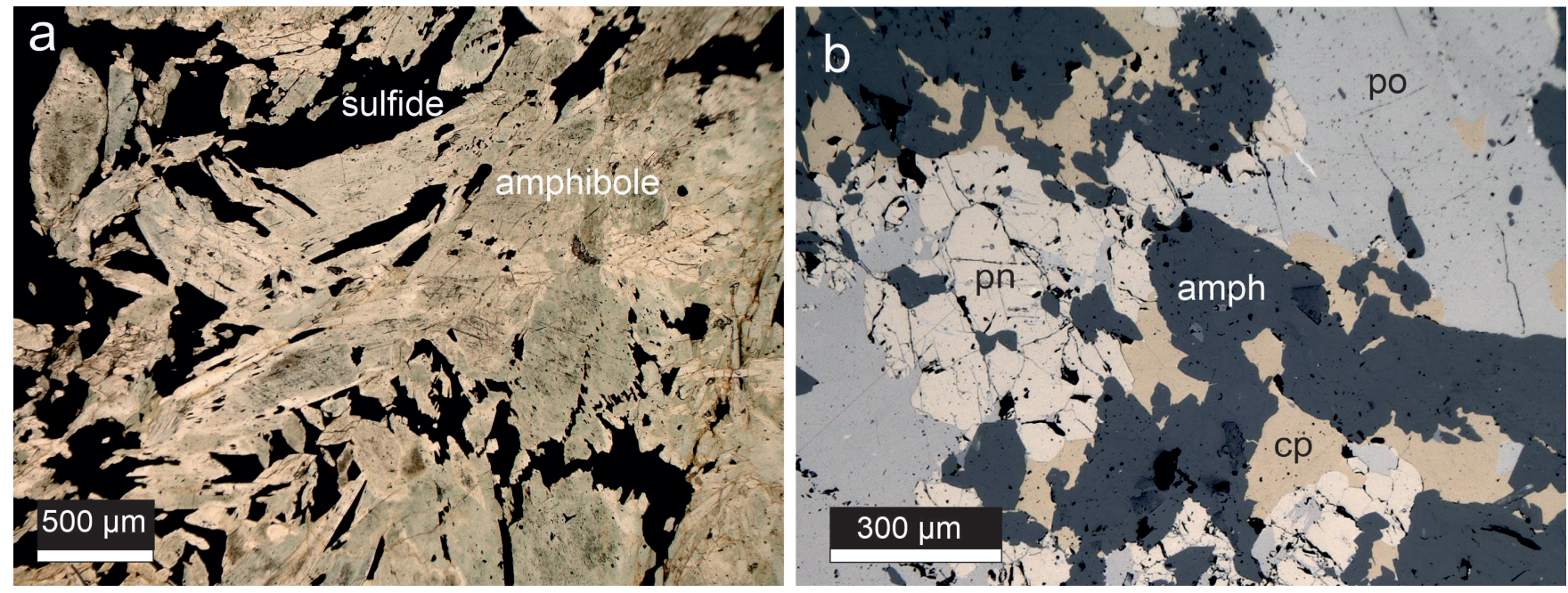

Figure 3. Microphotographs of sulfide-mineralized hornblendite. (a) Coarse crystals of zoned amphibole with interstitial sulfides, transmitted light; (b) pyrrhotite (po), pentlandite (pn) and chalcopyrite (cp) interstitial to amphibole (dark), reflected light. 
Table 1. Chemical analysis of sulfide ore samples from the Haidbach deposit.

\begin{tabular}{|c|c|c|c|c|c|c|c|c|}
\hline Element & Unit & HB3 & HB9 & P9 & P13 & P27 & Haid1 & Haid3 \\
\hline $\mathrm{SiO}_{2}{ }^{(1)}$ & $\%(m / m)$ & 25.28 & 27.98 & 20.996 & 29.84 & 30.15 & 25.82 & 39.71 \\
\hline $\mathrm{TiO}_{2}{ }^{(1)}$ & $\%(m / m)$ & 0.257 & 0.124 & 0.222 & 0.244 & 0.256 & 0.115 & 0.093 \\
\hline $\mathrm{Al}_{2} \mathrm{O}_{3}{ }^{(1)}$ & $\%(m / m)$ & 6.38 & 4.49 & 5.25 & 7.14 & 8.26 & 3.92 & 2.57 \\
\hline $\mathrm{Fe}_{2} \mathrm{O}_{3}{ }^{(1)}$ & $\%(m / m)$ & 28.8 & 32.8 & 42.5 & 30.3 & 30.0 & 31.7 & 26.7 \\
\hline $\mathrm{MgO}^{(1)}$ & $\%(\mathrm{~m} / \mathrm{m})$ & 6.41 & 9.41 & 7.07 & 11.89 & 11.84 & 8.70 & 6.90 \\
\hline $\mathrm{CaO}^{(1)}$ & $\%(m / m)$ & 10.44 & 6.34 & 4.27 & 5.81 & 6.47 & 7.06 & 4.98 \\
\hline $\mathrm{Na}_{2} \mathrm{O}^{(1)}$ & $\%(\mathrm{~m} / \mathrm{m})$ & $<0.01$ & 0.152 & 0.187 & 0.152 & 0.103 & 0.087 & 0.132 \\
\hline $\mathrm{K}_{2} \mathrm{O}^{(1)}$ & $\%(m / m)$ & 0.009 & 0.025 & 0.332 & 0.022 & 0.02 & 0.013 & 0.019 \\
\hline $\mathrm{P}_{2} \mathrm{O}_{5}{ }^{(3)}$ & $\%(m / m)$ & 0.034 & 0.023 & 0.032 & 0.034 & 0.037 & 0.060 & 0.032 \\
\hline$S^{(1)}$ & $\%(m / m)$ & 12.35 & 10.95 & 18.42 & 9.55 & 8.51 & 15.65 & 11.67 \\
\hline $\mathrm{Li}^{(3)}$ & $\mathrm{mg} / \mathrm{kg}$ & 7.9 & 2.8 & 3.3 & 2.5 & 3.9 & 2.2 & 1.4 \\
\hline $\mathrm{Be}^{(3)}$ & $\mathrm{mg} / \mathrm{kg}$ & 0.1 & 0.4 & 0.5 & 1.1 & 0.7 & 0.9 & 0.2 \\
\hline$V^{(2)}$ & $\mathrm{mg} / \mathrm{kg}$ & 58 & 75 & 80 & 117 & 132 & 43 & 33 \\
\hline $\mathrm{Cr}^{(1)}$ & $\mathrm{mg} / \mathrm{kg}$ & 1120 & 1590 & 930 & 1590 & 1510 & 876 & 600 \\
\hline$M n^{(3)}$ & $\mathrm{mg} / \mathrm{kg}$ & 809 & 1030 & 643 & 682 & 749 & 605 & 533 \\
\hline $\mathrm{Co}^{(2)}$ & $\mathrm{mg} / \mathrm{kg}$ & 1042 & 561 & 909 & 662 & 1334 & 536 & 682 \\
\hline $\mathrm{Ni} i^{(1)}$ & $\mathrm{mg} / \mathrm{kg}$ & 4770 & 20710 & 24630 & 10380 & 15930 & 16180 & 16930 \\
\hline $\mathrm{Cu}^{(1)}$ & $\mathrm{mg} / \mathrm{kg}$ & 21800 & 5650 & 14500 & 3360 & 8440 & 73130 & 18690 \\
\hline $\mathrm{Zn}^{(2)}$ & $\mathrm{mg} / \mathrm{kg}$ & 232 & 118 & 124 & 67 & 167 & 281 & 105 \\
\hline $\mathrm{Ga}^{(3)}$ & $\mathrm{mg} / \mathrm{kg}$ & 4.4 & 5.3 & 3.6 & 6.1 & 6.9 & 3.5 & 2.3 \\
\hline $\mathrm{Ge}^{(3)}$ & $\mathrm{mg} / \mathrm{kg}$ & $<0.1$ & $<0.1$ & $<0.1$ & $<0.1$ & $<0.1$ & $<0.1$ & $<0.1$ \\
\hline $\mathrm{As}^{(3)}$ & $\mathrm{mg} / \mathrm{kg}$ & 618 & 264 & 362 & 539 & 875 & 122 & 264 \\
\hline $\mathrm{Se}^{(3)}$ & $\mathrm{mg} / \mathrm{kg}$ & 57 & 53 & 79 & 42 & 41 & 48 & 48 \\
\hline$Y^{(3)}$ & $\mathrm{mg} / \mathrm{kg}$ & 2.2 & 2.5 & 3.9 & 4.9 & 5.2 & 2.2 & 1.8 \\
\hline $\mathrm{Zr}^{(2)}$ & $\mathrm{mg} / \mathrm{kg}$ & 12 & 8 & 10 & 12 & 12 & & \\
\hline $\mathrm{Mo}^{(3)}$ & $\mathrm{mg} / \mathrm{kg}$ & 1.08 & 2.03 & 2.21 & 1.7 & 4.23 & 2.36 & 1.32 \\
\hline $\mathrm{Ru}^{(2)}$ & $\mathrm{mg} / \mathrm{kg}$ & $<0.1$ & $<0.1$ & $<0.1$ & $<0.1$ & 0.1 & & \\
\hline $\mathrm{Rh}^{(2)}$ & $\mathrm{mg} / \mathrm{kg}$ & $<0.02$ & $<0.02$ & $<0.02$ & $<0.02$ & $<0.02$ & & \\
\hline $\mathrm{Pd}^{(4)}$ & $\mu \mathrm{g} / \mathrm{kg}$ & 205 & 949 & 864 & 166 & 2470 & 1110 & 1010 \\
\hline $\mathrm{Ag}^{(3)}$ & $\mathrm{mg} / \mathrm{kg}$ & 8.9 & 3.9 & 6.9 & 2.4 & 4.8 & 22.8 & 7.1 \\
\hline $\mathrm{Cd}^{(3)}$ & $\mathrm{mg} / \mathrm{kg}$ & 3.2 & 1.0 & 1.0 & 0.6 & 1.6 & 8.3 & 1.9 \\
\hline $\ln (3)$ & $\mathrm{mg} / \mathrm{kg}$ & 0.1 & $<0.1$ & $<0.1$ & $<0.1$ & $<0.1$ & 0.2 & $<0.1$ \\
\hline $\mathrm{Sn}^{(3)}$ & $\mathrm{mg} / \mathrm{kg}$ & 1.0 & 1.0 & 1.0 & 1.0 & 1.0 & 2.0 & 1.0 \\
\hline $\mathrm{Sb}^{(3)}$ & $\mathrm{mg} / \mathrm{kg}$ & 1.7 & 0.6 & 0.9 & 0.8 & 1.4 & 0.5 & 0.5 \\
\hline $\mathrm{Te}^{(3)}$ & $\mathrm{mg} / \mathrm{kg}$ & 3.8 & 8.1 & 5.6 & 2.0 & 4.3 & 3.8 & 4.9 \\
\hline $\mathrm{Cs}^{(3)}$ & $\mathrm{mg} / \mathrm{kg}$ & 0.18 & 0.20 & 10.50 & 0.21 & 0.44 & 0.13 & 0.09 \\
\hline $\mathrm{Ba}^{(3)}$ & $\mathrm{mg} / \mathrm{kg}$ & 6 & $<1$ & 77 & 1 & 2 & $<1$ & 1 \\
\hline$W^{(2)}$ & $\mathrm{mg} / \mathrm{kg}$ & 5.2 & 4.7 & 4.5 & 4.1 & 3.8 & 3.2 & 1.5 \\
\hline $\operatorname{Re}^{(3)}$ & $\mathrm{mg} / \mathrm{kg}$ & 0.088 & 0.192 & 0.233 & 0.206 & 0.192 & 0.134 & 0.075 \\
\hline Ir ${ }^{(2)}$ & $\mathrm{mg} / \mathrm{kg}$ & $<0.015$ & $<0.015$ & $<0.015$ & 0.02 & 0.02 & & \\
\hline $\mathrm{Pt}^{(4)}$ & $\mu \mathrm{g} / \mathrm{kg}$ & 365 & 239 & 1010 & 149 & 258 & 510 & 535 \\
\hline $\mathrm{Au}^{(4)}$ & $\mu \mathrm{g} / \mathrm{kg}$ & 205 & 59 & 122 & 62 & 172 & 356 & 105 \\
\hline $\mathrm{Hg}^{(3)}$ & $\mu \mathrm{g} / \mathrm{kg}$ & 2560 & 70 & 30 & 20 & 20 & $<10$ & 1430 \\
\hline $\mathrm{Pb}^{(3)}$ & $\mathrm{mg} / \mathrm{kg}$ & 13.8 & 3.0 & 6.0 & 5.6 & 4.6 & 4.4 & 2.9 \\
\hline$B i^{(3)}$ & $\mathrm{mg} / \mathrm{kg}$ & 1.8 & 1.3 & 1.1 & 0.7 & 1.0 & 0.8 & 0.9 \\
\hline
\end{tabular}

Method: (1) XRF (MUL); (2) ICP-MS (MUL); (3) TD-MS (Actlabs); (4) FA-MS (Actlabs) 

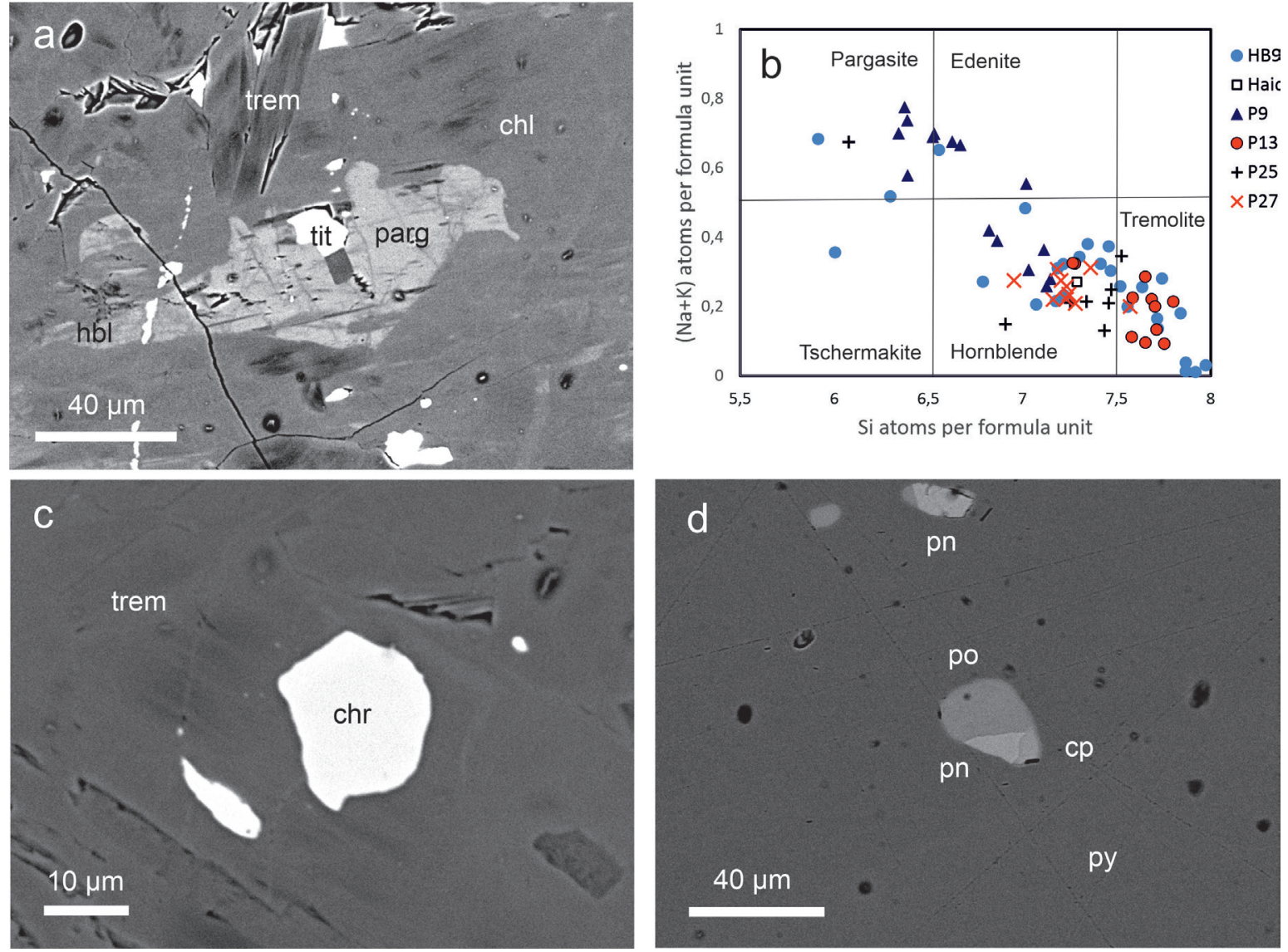

Figure 4. BSE images of host rock and mineralization. (a) Zoned amphibole associated with titanite (tit) and chlorite (chl); parg, pargasite; hbl, hornblende; trem, tremolite. (b) Amphibole compositions in a Si versus (Na+K) diagram for different hornblendite samples from the Haidbach ore; (c) chromian spinel (chr) enclosed by tremolite (trem), sample HB9; (d) polyphase melt inclusions in pyrite (py), P13; cp, chalcopyrite; po, pyrrhotite; pn, pentlandite.

Heavy minerals from two well-mineralized samples (P12, P25) collected from massive sulfide ore in the middle level of the mine were concentrated using the hydroseparation technique (Rudashevsky et al., 2001, 2002) following conventional grinding and sieving. Subsequent monolayer polished sections were prepared at the University of Barcelona as outlined by Aiglsperger et al. (2015). BSE images and EDX spectra were taken for quality analysis using a FEG E-SEM Quanta 200. Polished blocks of the $<125 \mu \mathrm{m}$ fractions of these samples were analysed using the Smart $\mathrm{PI}^{\circledR}$ software on a ZEISS EVO 10 SEM in order to provide mineral abundances and granulometric data for $\mathrm{Cu}, \mathrm{Ni}$ and Fe sulfides measured in $15 \times 15 \mathrm{~mm}$ areas. The method identifies regions of interest (in this case: Fe-Ni-Cu sulfide phases) using a combination of particle detection via BSE images and EDX spectra acquired on identified particles.

Whole-rock chemical analysis was performed using X-ray fluorescence analysis (XRF; Panalytical WDX and Spectroscout EDX) and inductively coupled plasma mass spectrometry (ICP-MS) at the Chair of General and Analytical Chemistry, Montanuniversität Leoben (MUL). For XRF analysis, $1 \mathrm{~g}$ of ignited powdered rock (agate disc mill) was melted to glass beads in platinum crucibles with $8 \mathrm{~g}$ lithium tetraborate. Powder pellets of sulfide-rich samples were prepared by pressing $4 \mathrm{~g}$ sample powder with wax. The mass fractions of trace elements were determined using Agilent 7500cx and Agilent 8800 inductively coupled plasma mass spectrometers after dissolution of $0.1 \mathrm{~g}$ sample powder in $\mathrm{Na}_{2} \mathrm{O}_{2}$ (Meisel et al., 2002; Bokhary and Meisel, 2017). Major and trace element mass fractions were also determined at Activation Laboratories, Canada, using packages 1C-EXP2 und Ultratrace 6 (www.actlabs.com). The mass fractions of Pt, Pd and $\mathrm{Au}$ were analysed by fire assay-MS with detection limits of $0.5 \mu \mathrm{g} / \mathrm{kg}$ for Pt and Pd, and $1 \mu \mathrm{g} / \mathrm{kg}$ for Au. Re was determined by total dissolution-MS with detection limits of 1 $\mu \mathrm{g} / \mathrm{kg}$. Method comparison showed good correlations for trace elements between the commercial laboratory and solution-ICP-MS data generated at MUL. The more substantial differences for $\mathrm{Au}, \mathrm{Pt}$ and $\mathrm{Pd}$ are attributed to the heterogeneous distribution of microphases in the samples, hence sampling issues.

Trace element compositions in $\mathrm{Cu}$ and Fe sulfides were analysed in situ by laser ablation ICP-MS at MUL, employing a New Wave Research Nd:YAG $213 \mathrm{~nm}$ nano second laser ablation system coupled to an Agilent 8800 triple quadrupole ICP-MS/MS. The laser beam was focussed to a spot size of $50 \mu \mathrm{m}$ at $10 \mathrm{~Hz}$ and $2-3 \mathrm{~J} / \mathrm{cm}^{2}$. Helium (750 mL/min), mixed with argon (900 mL/min) using a Liebig gas mixing device was used as carrier gas. The following signals at $\mathrm{m} / \mathrm{z}$ corresponding to the following isotopes were measured using acquisition times between 0.02 and 0.05 seconds: ${ }^{34} \mathrm{~S},{ }^{51} \mathrm{~V},{ }^{52} \mathrm{Cr},{ }^{55} \mathrm{Mn},{ }^{57} \mathrm{Fe},{ }^{59} \mathrm{Co},{ }^{60} \mathrm{Ni}$, 
Table 2. Trace element composition of pyrrhotite ( $n=17)$, pyrite (68) and chalcopyrite (53) from the Haidbachgraben ore, Felbertal, Salzburg. LA-ICP-MS data; bdl, below detection limit; cps: counts per second; Md: median; P25; $25^{\text {th }}$ percentile; P75: $75^{\text {th }}$ percentile.

\begin{tabular}{|c|c|c|c|c|c|c|c|c|c|}
\hline & Pyrrhotite & & & Pyrite & & & alcopyrite & & \\
\hline$(\mathrm{mg} / \mathrm{kg})$ & Md & P75 & P25 & Md & P75 & P25 & $\mathrm{Md}$ & P75 & P25 \\
\hline $\mathrm{Mn}$ & 12.96 & 18.76 & 10.43 & 12.76 & 16.57 & 11.05 & 8.1 & 27 & 6.5 \\
\hline Co & 40 & 133 & 0.19 & 3754 & 6675 & 2818 & 0.35 & 1.37 & 0.08 \\
\hline $\mathrm{Ni}$ & 5710 & 8420 & 4540 & 934 & 1346 & 695 & 64 & 240 & 38 \\
\hline $\mathrm{Cu}$ & 3.3 & 112 & 0.7 & 54 & 282 & 2.8 & & & \\
\hline $\mathrm{Zn}$ & 2.0 & 2.3 & 1.35 & 2.9 & 4.9 & 2.2 & 568 & 730 & 456 \\
\hline $\mathrm{Ga}$ & 0.04 & 0.05 & 0.03 & 0.04 & 0.08 & 0.04 & 0.09 & 0.15 & 0.06 \\
\hline $\mathrm{Ge}$ & 0.87 & 0.98 & 0.82 & 0.26 & 0.42 & 0.21 & 0.57 & 0.68 & 0.50 \\
\hline As & 0.20 & 0.96 & 0.03 & 2880 & 3673 & 1157 & 1.1 & 3.9 & 0.4 \\
\hline $\mathrm{Se}$ & 160 & 168 & 147 & 37 & 73 & 28 & 98 & 117 & 86 \\
\hline Mo & 0.059 & 0.067 & 0.041 & 0.010 & 0.021 & 0.010 & 0.013 & 0.035 & 0.010 \\
\hline $\mathrm{Ag}$ & 1.56 & 14.2 & 0.99 & 0.098 & 0.34 & 0.012 & 33.5 & 58.8 & 20.7 \\
\hline $\mathrm{Cd}$ & 0.23 & 0.55 & bdl & 0.03 & 0.28 & bdl & 51 & 70 & 35 \\
\hline In & 0.003 & 0.006 & bdl & 0.004 & 0.006 & 0.002 & 2.0 & 2.7 & 0.9 \\
\hline Sn & 0.058 & 0.082 & 0.024 & 0.002 & 0.021 & bdl & 4.1 & 7.9 & 1.8 \\
\hline $\mathrm{Sb}$ & 0.021 & 0.168 & 0.006 & 0.26 & 0.55 & 0.09 & 0.34 & 0.69 & 0.16 \\
\hline $\operatorname{Re}(\mathrm{cps})$ & 70 & & & 19 & & & 4 & & \\
\hline $\mathrm{Au}$ & bdl & 0.012 & bdl & 0.003 & 0.022 & bdl & 0.04 & 0.08 & 0.008 \\
\hline $\mathrm{Hg}$ & 0.43 & 0.61 & 0.15 & 0.02 & 0.12 & bdl & 1.03 & 1.99 & 0.44 \\
\hline TI & 0.004 & 0.063 & 0.001 & 0.002 & 0.009 & bdl & 0.027 & 0.12 & 0.007 \\
\hline $\mathrm{Pb}$ & 2.35 & 3.89 & 1.36 & 1.6 & 3.3 & 0.3 & 7.6 & 15.5 & 5.1 \\
\hline $\mathrm{Bi}$ & 0.38 & 0.55 & 0.27 & 0.47 & 1.26 & 0.11 & 0.29 & 0.49 & 0.12 \\
\hline $\mathrm{Co} / \mathrm{Ni}$ & 0.005 & 0.014 & $<0.01$ & 3.64 & 6.6 & 2.3 & 0.003 & 0.011 & 0.0005 \\
\hline
\end{tabular}

${ }^{63} \mathrm{Cu},{ }^{66} \mathrm{Zn},{ }^{71} \mathrm{Ga},{ }^{74} \mathrm{Ge},{ }^{75} \mathrm{As},{ }^{82} \mathrm{Se},{ }^{95} \mathrm{Mo},{ }^{107} \mathrm{Ag},{ }^{111} \mathrm{Cd},{ }^{115} \mathrm{In}$, ${ }^{118} \mathrm{Sn},{ }^{121} \mathrm{Sn},{ }^{197} \mathrm{Au},{ }^{210} \mathrm{Hg},{ }^{205} \mathrm{Tl},{ }^{208} \mathrm{~Pb}$ and ${ }^{209} \mathrm{Bi}$. For quantification of the element content, the matrix-matched sintered pressed powder pellet reference material (MUL-ZnS 1; Onuk et al., 2017) and for quality control, the USGS powder pressed polysulfide reference material MASS-1 (Wilson et al., 2002) were used. ${ }^{185}$ Re was measured but not quantified due to the lack of a suitable reference material. The software package lolite V3.1 (Paton at al., 2011) was used for data reduction.

\section{Results}

\subsection{Petrography of host rocks and ore}

Chlorite-epidote schist and albite-epidote-chlorite schist grading into albite gneiss are the dominant lithologies in the immediate vicinity of the mine site and constitute host rocks to the ore. The schists and gneisses are composed of chlorite, albite, epidote, titanite, calcite, rare quartz, muscovite, biotite, and zircon and apatite as accessories. A disseminated sulfide mineralization consists of pyrite and chalcopyrite, accompanied by very minor sphalerite. In the mine adits, amphibole-rich rocks are the major host of the massive $\mathrm{Cu}$-Ni-rich sulfide-mineralized zone. These rocks are composed of calcic amphibole with minor chlorite, titanite, rare epidote, albite, quartz and calcite (Fig. 3a). Notably, Cr-rich spinel was identified as a minor phase (Fig. 4c). Due to the very limited amount of feldspar, these rocks are referred to as hornblendite. In the wider area surrounding the former mine site, "true" amphibolites of variable grain size and texture are encountered, but not within the underground exposures.

Massive sulfide ore (Fig. 3b) is found in about four layers or lenses that can be followed for several decametres along strike. The ore zone comprises centimetre-wide sulfide-rich veinlets in a zone 1-3 metres thick that is mainly composed of hornblendite. More massive ores occur at several locations, but they are highly deformed by folding and crumpling, related to formation of a crenulation cleavage. Additional rock types within the mine sequence comprise crosscutting tourmaline-calcite-quartz veins, massive quartz veins, and carbonate veins. According to UV prospection, mine stopes are free of macroscopically visible scheelite. Foliation planes in the mine mainly dip to the N, NW and S, forming a large anticlinal fold with a fold axis $B=260 / 20$.

\subsection{Host rock mineralogy and mineral chemistry}

Host rocks have been studied using optical microscopy and SEM in order to characterize the major rock-forming 
Table 3. Precious metal-bearing phases and other rare minerals identified in sulfide ore at Haidbach. In situ observations in polished sections of ore, and in hydroseparation (HS) concentrates.

\begin{tabular}{|c|c|c|c|c|c|}
\hline Mineral & Formula & Abundance & In situ observations & HS Conc. P12 & HS Conc. P25 \\
\hline Argentopentlandite & $(\mathrm{Ni}, \mathrm{Fe}, \mathrm{Ag})_{9} \mathrm{~S}_{8}$ & $\mathrm{x}$ & 3 & 1 & 2 \\
\hline Argentite & $\mathrm{Ag}_{2} \mathrm{~S}$ & $x$ & & & 3 \\
\hline Bournonite & $\mathrm{CuPbSbS}_{3}$ & $x$ & & 2 & \\
\hline Cobaltite & CoAsS & $x x$ & 25 & & 1 \\
\hline Cubanite & $\mathrm{CuFe}_{2} \mathrm{~S}_{3}$ & $x$ & 1 & & \\
\hline Electrum & $\mathrm{Au}, \mathrm{Ag}$ & $x x$ & 4 & 27 & 3 \\
\hline Empressite (?) & AgTe & $x$ & 1 & & 1 \\
\hline Galena & $\mathrm{PbS}$ & $x$ & 3 & & 9 \\
\hline Gersdorffite & $\mathrm{NiAsS}$ & $x x x$ & $>40$ & 8 & $>26$ \\
\hline Hessite & $\mathrm{Ag}_{2} \mathrm{Te}$ & $x x x$ & $>29$ & $>58$ & 7 \\
\hline Irarsite & IrAsS & $x$ & 5 & & \\
\hline Keithconnite & $\mathrm{Pd}_{20} \mathrm{Te}_{7}$ & $x$ & 1 & & \\
\hline Kotulskite & PdTe & $x$ & 1 & & \\
\hline Melonite & $\mathrm{NiTe}_{2}$ & $x$ & & 2 & 9 \\
\hline Merenskyite & $\mathrm{PdTe}_{2}$ & $x x$ & 20 & $>25$ & 1 \\
\hline Michenerite & $\mathrm{PdTe}(\mathrm{Bi}, \mathrm{Sb})$ & $x x$ & 7 & 19 & \\
\hline Molybdenite & $\mathrm{MoS}_{2}$ & $\mathrm{xx}$ & 10 & 1 & 1 \\
\hline Pd-melonite & $(\mathrm{Ni}, \mathrm{Pd}) \mathrm{Te}_{2}$ & $x x x$ & $>58$ & $>69$ & 4 \\
\hline Petzite & $\mathrm{Ag}_{3} \mathrm{AuTe}_{2}$ & $\mathrm{x}$ & & 2 & 1 \\
\hline Platinum & $\mathrm{Pt}$ & $\mathrm{x}$ & 1 & & \\
\hline Skutterudite & $\mathrm{CoAs}_{3}$ & $x$ & & & 2 \\
\hline Sphalerite & ZnS & $x x$ & $>11$ & 2 & 3 \\
\hline Sperrylite & $\mathrm{PtAs}_{2}$ & $x x$ & 22 & $>40$ & 3 \\
\hline Sudburyite & $\mathrm{PdSb}$ & $x$ & 4 & 1 & \\
\hline Tarkianite & $(\mathrm{Cu}, \mathrm{Fe})(\mathrm{Re}, \mathrm{Mo})_{4} \mathrm{~S}_{8}$ & $x x$ & 26 & & 20 \\
\hline Testibiopalladite & $\mathrm{PdTe}(\mathrm{Sb}, \mathrm{Te})$ & $x$ & 11 & 1 & \\
\hline Tetraferroplatinum & PtFe & $x$ & & & 1 \\
\hline Tiemannite & $\mathrm{HgSe}$ & $x$ & & & 1 \\
\hline $\begin{array}{l}\text { Re-Pb sulfide } \\
\text { (dzhezkazghanite?) }\end{array}$ & $(\mathrm{Re}, \mathrm{Pb}, \mathrm{Cu}, \mathrm{Mo})_{5} \mathrm{~S}_{6}$ & $x$ & 3 & & 4 \\
\hline Pd-Te-Bi phase & $\operatorname{PdTe}(\mathrm{Te}, \mathrm{Bi})$ & $x$ & & 2 & 1 \\
\hline
\end{tabular}

$\mathrm{x}$ : rare; $\mathrm{xxx}$ : moderately abundant; $\mathrm{xxx}$ : more frequent

Numbers indicate number of observations in polished section in situ and in hydroseparation concentrates P12 and P25;

$>$ indicates that more than the quoted number of grains are present but were not documented in detail

minerals. The immediate host rock of the Cu-Ni sulfide ore is hornblendite free of garnet, poor in biotite, and essentially composed of chlorite, amphibole, epidote, titanite and albite. Amphibole forms elongate acicular crystals of about $1 \mathrm{~mm}$ size often intergrown with chlorite (Figs. 3a, 4a). Calcic amphibole compositions are Si-rich (7-8 atoms per formula unit based on 23 oxygen, apfu Si), comprising actinolite-tremolite and hornblende with $\mathrm{XMg}(\mathrm{Mg} /(\mathrm{Mg}+$ Fetot $))=0.7-0.8$ (Fig. 4b). Relics of pargasitic amphibole are occasionally observed, with $\mathrm{Si}=$ 6.0-6.5 apfu, $\mathrm{Na}+\mathrm{K}=0.6-0.8$ apfu and lower XMg (0.45$0.55)$ (Fig. 4b). These are replaced by actinolitic to tremolitic amphibole and chlorite. Elevated concentrations of $\mathrm{Cr}$ in the amphiboles are noteworthy (on average $\left.0.35 \%(\mathrm{~m} / \mathrm{m}) \mathrm{Cr}_{2} \mathrm{O}_{3}\right)$. Chlorite is omnipresent in all lithological units. The compositions range from $\mathrm{Si}=4.0-5.7$ apfu (based on 28 oxygen) and $\mathrm{XMg}=0.45-0.65 ; \mathrm{Cr}_{2} \mathrm{O}_{3}$ averages to $0.6 \%(\mathrm{~m} / \mathrm{m})$. Rare feldspar is pure albite, with $<1 \%$ anorthite component. Biotite was observed in few samples only, whereas muscovite occurs in minor amounts. Abundant tourmaline in a crosscutting vein structure is of intermediate schorl-dravite composition with $\mathrm{Na} /(\mathrm{Na}+\mathrm{Ca})>0.9$ and $\mathrm{XMg}=0.45-0.55$. Titanium-rich phases in the host rocks comprise abundant titanite with occasional inclusions of rutile. Ilmenite is present in most samples including the tourmalinite vein 
Table 4. Representative EDX analyses (ZEISS ${ }^{\oplus}$ EVO MA10 SEM) of accessory minerals in Haidbach sulfide ore. Analytical totals are normalized to $100 \%$; in some cases, contribution from host minerals has been subtracted.

\begin{tabular}{|c|c|c|c|c|c|c|c|c|c|c|}
\hline & 1 & 2 & 3 & 4 & 5 & 6 & 7 & 8 & 9 & 10 \\
\hline \multicolumn{11}{|c|}{$\%(\mathrm{~m} / \mathrm{m})$} \\
\hline$S$ & 33.04 & 18.29 & 18.86 & 17.79 & 0.10 & & & & 31.09 & 14.17 \\
\hline $\mathrm{Fe}$ & 5.62 & 4.07 & 7.08 & 9.74 & 3.55 & & & & 34.62 & \\
\hline Co & 0.21 & & 14.89 & 7.36 & 18.58 & & & & & \\
\hline $\mathrm{Ni}$ & & & 13.32 & 20.80 & 2.49 & & & & 22.12 & \\
\hline $\mathrm{Cu}$ & & 11.26 & & & & & & & & \\
\hline $\mathrm{Zn}$ & 58.67 & & & & & & & & & \\
\hline As & & & 44.92 & 44.31 & 75.27 & & & & & \\
\hline $\mathrm{Cd}$ & 2.45 & & & & & & & & & \\
\hline $\mathrm{Sb}$ & & 20.97 & & & & & & & & \\
\hline $\mathrm{Te}$ & & & & & & 37.33 & & 34.19 & & \\
\hline $\mathrm{Pt}$ & & & 0.92 & & & & & & & \\
\hline $\mathrm{Au}$ & & & & & & & 84.01 & 24.55 & & \\
\hline $\mathrm{Pb}$ & & 45.41 & & & & & & & & \\
\hline \multicolumn{11}{|l|}{ at $\%$} \\
\hline$S$ & 50.18 & 47.07 & 25.37 & 24.12 & 0.22 & & & & 46.64 & 35.71 \\
\hline $\mathrm{Fe}$ & 4.90 & 6.02 & 8.31 & 11.52 & 4.45 & & & & 29.81 & \\
\hline $\mathrm{Ni}$ & & & 12.20 & 19.21 & 2.97 & & & & 18.12 & \\
\hline $\mathrm{Cu}$ & & 14.62 & & & & & & & & \\
\hline $\mathrm{Zn}$ & 43.69 & & & & & & & & & \\
\hline As & & & 37.12 & 36.89 & 70.29 & & & & & \\
\hline $\mathrm{Ag}$ & 0.00 & & & & & 66.51 & 25.79 & 49.35 & 5.43 & 64.29 \\
\hline $\mathrm{Cd}$ & 1.06 & & & & & & & & & \\
\hline $\mathrm{Sb}$ & & 14.21 & & & & & & & & \\
\hline $\mathrm{Te}$ & & & & & & 33.49 & & 34.57 & & \\
\hline $\mathrm{Pt}$ & & & 0.42 & & & & & & & \\
\hline $\mathrm{Au}$ & & & & & & & 74.21 & 16.08 & & \\
\hline $\mathrm{Pb}$ & & 18.08 & & & & & & & & \\
\hline
\end{tabular}

1: Sphalerite, section P25_50-75 $\mu \mathrm{m}$, analysis 191; anhedral grain $11 \times 5 \mu \mathrm{m}$ in pentlandite

2: Bournonite, section P12, analysis 6; euhedral grain $2.5 \times 2.5 \mu \mathrm{m}$ at rim of pyrrhotite

3: Cobaltite, section P27, analysis 67 ; euhedral inclusion in sulfide, $5 \times 3.5 \mu \mathrm{m}$

4: Gersdorffite, section P25_50-75 $\mu \mathrm{m}$, analysis 204 ; anhedral grain $10 \times 5 \mu \mathrm{m}$ in composite inclusion at pyrrhotite rim

5: Skutterudite, section P25_50-75 $\mu \mathrm{m}$, analysis 45 ; anhedral grain $7 \times 3 \mu \mathrm{m}$ at pyrite rim

6: Hessite, section P12B_<30 $\mu \mathrm{m}$, analysis 95 ; anhedral grain $30 \times 25 \mu \mathrm{m}$ in composite inclusion with Pd melonite

7: Electrum, section P12B_<30 $\mu \mathrm{m}$, analysis 80 ; anhedral grain $30 \times 15 \mu \mathrm{m}$

8: Petzite, section P12B_<30 $\mu \mathrm{m}$, analysis 55; grain in composite inclusion

9: Argentopentlandite, section P12B_30-50 $\mu \mathrm{m}$, analysis 35; grain $10 \times 6 \mu \mathrm{m}$ intergrown with hessite

10: Argentite/acanthite, section P25_30-50 $\mu \mathrm{m}$, analysis 19 ; euhedral grain $7 \times 4.5 \mu \mathrm{m}$ attached to pyrite

\begin{tabular}{|c|c|c|c|c|c|c|c|c|c|c|}
\hline & 11 & 12 & 13 & 14 & 15 & 16 & 17 & 18 & 19 & 20 \\
\hline \multicolumn{11}{|c|}{$\%(\mathrm{~m} / \mathrm{m})$} \\
\hline $\mathrm{s}$ & & 9.68 & & & & & & & & \\
\hline $\mathrm{Fe}$ & & 2.62 & & & & & & & & \\
\hline Co & & 2.35 & & & & & & & & \\
\hline $\mathrm{Ni}$ & & 0.92 & 12.06 & 1.18 & & & 4.67 & 0.25 & & \\
\hline As & 43.51 & 30.82 & & & & & & & & \\
\hline $\mathrm{Rh}$ & & 1.67 & & & & & & & & \\
\hline $\mathrm{Pd}$ & 0.18 & & 10.10 & 27.21 & 26.89 & 27.93 & 27.44 & 47.25 & 37.91 & 64.56 \\
\hline $\mathrm{Sb}$ & 0.69 & & 2.49 & 6.27 & 10.97 & 30.16 & 16.81 & 52.50 & & 5.35 \\
\hline $\mathrm{Te}$ & & & 71.93 & 64.71 & 32.69 & 33.38 & 43.49 & & 43.87 & 21.10 \\
\hline Ir & & 43.96 & & & & & & & & \\
\hline $\mathrm{Pt}$ & 55.61 & 7.98 & & & 0.23 & & & & & \\
\hline $\mathrm{Bi}$ & & & 3.42 & 0.64 & 28.63 & 8.53 & 7.61 & & 18.22 & 8.99 \\
\hline \multicolumn{11}{|l|}{ at $\%$} \\
\hline $\mathrm{S}$ & & 27.40 & & & & & & & & \\
\hline $\mathrm{Fe}$ & & 4.26 & & & & & & & & \\
\hline Co & & 3.61 & & & & & & & & \\
\hline As & 66.51 & 37.35 & & & & & & & & \\
\hline $\mathrm{Rh}$ & & 1.48 & & & & & & & & \\
\hline $\mathrm{Pd}$ & 0.20 & & 10.53 & 30.53 & 34.03 & 32.30 & 30.24 & 50.49 & 45.25 & 70.63 \\
\hline $\mathrm{Ag}$ & & & & & 0.73 & & & & & \\
\hline $\mathrm{Sb}$ & 0.65 & & 2.27 & 6.15 & 12.13 & 30.48 & 16.19 & 49.03 & & 5.11 \\
\hline $\mathrm{Te}$ & & & 62.57 & 60.56 & 34.50 & 32.19 & 39.98 & & 43.67 & 19.25 \\
\hline Ir & & 20.77 & & & & & & & & \\
\hline $\mathrm{Pt}$ & 32.64 & 3.72 & & & 0.16 & & & & & \\
\hline $\mathrm{Bi}$ & & & 1.82 & 0.37 & 18.45 & 5.02 & 4.27 & & 11.07 & 5.00 \\
\hline
\end{tabular}

11: Sperrylite, section P12B_<30 $\mu \mathrm{m}$, analysis 46 ; single subhedral grain $18 \times 15 \mu \mathrm{m}$

12: Irarsite, section $\mathrm{P9}$, analysis 28 ; euhedral grain $3 \times 2 \mu \mathrm{m}$ in group of 4 inclusions in actinolite

13: Palladian melonite, section P12_30-50 um, analysis 2; single subhedral grain $64 \times 36 \mu \mathrm{m}$

14: Merenskyite, section P12_<30 $\mu \mathrm{m}$, analysis 19 ; single subhedral grain $22 \times 11 \mu \mathrm{m}$

15: Michenerite, section P12_30-50 $\mu \mathrm{m}$, analysis 33; euhedral grain $20 \times 17 \mu \mathrm{m}$ in hessite

16: Michenerite-(Sb), section HB9, analysis 90; anhedral grain $10 \times 4 \mu \mathrm{m}$ at contact of pyrite and chalcopyrite

17: Testibiopalladite, section P28, analysis 1; subhedral grain $6 \times 3 \mu \mathrm{m}$ in crack between pyrite and chalcopyrite

18: Sudburyite, section $\mathrm{P} 12 \mathrm{~B}<30 \mu \mathrm{m}$, analysis 50 ; anhedral grain $7 \times 5.5 \mu \mathrm{m}$ in composite inclusion with petzite and $\mathrm{Pd}$ melonite

19: Kotulskite, section $\mathrm{P} 3$, analysis 49 ; anhedral grain $5 \mu \mathrm{m}$ at pyrite rim towards silicate matrix

20: Keithconnite, section P27, analysis 214 ; subhedral grain $4 \times 4 \mu \mathrm{m}$ at contact of pyrite and chalocpyrite 


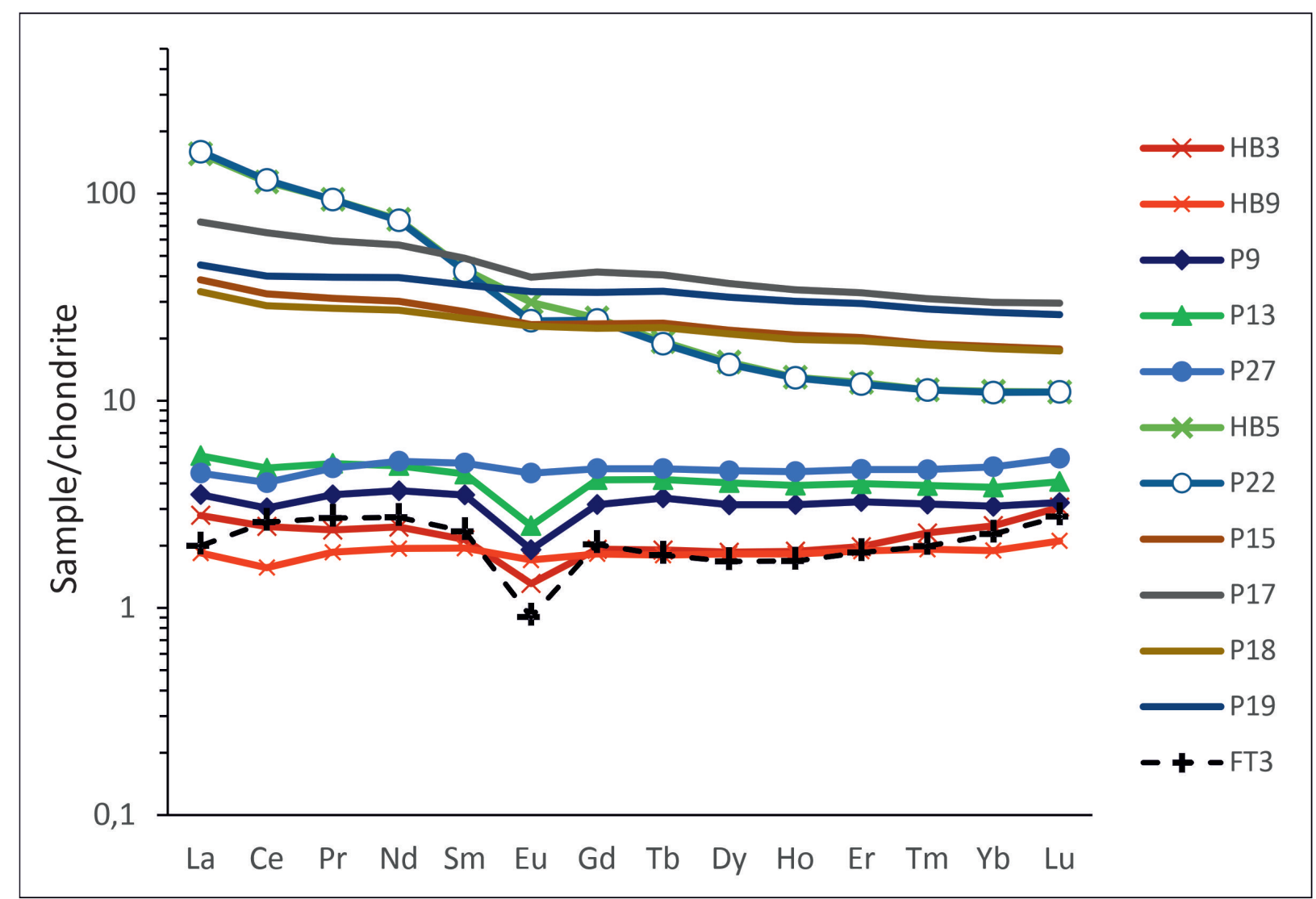

Figure 5. Chondrite-normalized REE patterns of mineralized hornblendite (HB3, HB9, P9, P13, P27), albite-epidote-gneiss (HB5, P22) and amphibolite (P15, P17, P18, P19) from the Haidbach mineralization and host rocks. FT3 is serpentinite from Hintersee, $7 \mathrm{~km}$ to the south of Haidbach (Melcher et al., 2002).

and is Mn-bearing (1.5-3.6\%(m/m) MnO). A few grains of relict chromian spinel were determined, either included in sulfide, or in amphibole-chlorite matrix (Fig. 4c). All spinel grains are $\mathrm{Zn}$-bearing $(2.3-4.4 \%(\mathrm{~m} / \mathrm{m}) \mathrm{ZnO})$ and virtually free of $\mathrm{Mg}(<0.5 \%(\mathrm{~m} / \mathrm{m}) \mathrm{MgO}) . \mathrm{Cr} /(\mathrm{Cr}+\mathrm{Al})$ ranges from 0.6 to 0.9 . Further accessories include zircon, baddeleyite, monazite, orthite, apatite, barite and calcite.

\subsection{Host rock and sulfide ore geochemistry}

A large number of analytical results for $\mathrm{Cu}, \mathrm{Ni}$ and $\mathrm{Co}$ are available from exploration reports (Seifriedsberger, 2015). Median concentrations for these elements in various ore types published in reports for 1911 and 1938 are $1.75 \%(\mathrm{~m} / \mathrm{m}) \mathrm{Cu}, 2.35 \%(\mathrm{~m} / \mathrm{m}) \mathrm{Ni}$ and $0.25 \%(\mathrm{~m} / \mathrm{m}) \mathrm{Co}$. In this project, major and trace elements were analysed in mineralized samples from mine stopes and small ore piles within the mine (Tab. 1). The Fe-rich sulfide ores (15-30 \%(m/m) total Fe, 6-12\%(m/m) S) have Cu ranging from $0.2-7 \%(\mathrm{~m} / \mathrm{m})$, Ni from $0.2-2.5 \%(\mathrm{~m} / \mathrm{m})$ and Co from $0.05-0.13 \%(\mathrm{~m} / \mathrm{m})$. The ore is also characterized by high $\mathrm{Cr}(229-1038 \mathrm{mg} / \mathrm{kg})$, As (122-875 mg/kg), Se (41-79 mg/kg), and low Zn (67-281 mg/kg) and Pb (2-14 $\mathrm{mg} / \mathrm{kg}$ ). The precious metals (defined here as the PGE plus $\mathrm{Au}, \mathrm{Ag}$ and $\mathrm{Re}$ ) range from $149-2470 \mu \mathrm{g} / \mathrm{kg}$ for Pt, $166-1110 \mu \mathrm{g} / \mathrm{kg}$ for Pd, 59-356 $\mu \mathrm{g} / \mathrm{kg}$ for Au and $75-270 \mu \mathrm{g} / \mathrm{kg}$ for Re. Ru $(<100 \mu \mathrm{g} / \mathrm{kg}), \mathrm{Rh}(<20 \mu \mathrm{g} / \mathrm{kg})$ and $\operatorname{Ir}(<20 \mu \mathrm{g} / \mathrm{kg})$ are below detection limits, whereas Ag ranges from 2.4 to $22.8 \mathrm{mg} / \mathrm{kg}$. Semimetals commonly associated with platinum-group metals have low to moderate concentrations, e.g. $\mathrm{Bi}(2 \mathrm{mg} / \mathrm{kg}), \mathrm{Sb}(<2 \mathrm{mg} / \mathrm{kg})$ and Te $(2-8 \mathrm{mg} / \mathrm{kg})$. Mo and W reach up to $5 \mathrm{mg} / \mathrm{kg}$.

Average PGE tenors, calculated using the formula according to Barnes and Lightfoot (2005) and corrected for contribution of $\mathrm{Ni}$ in silicate, are $2.6 \mathrm{mg} / \mathrm{kg} \mathrm{Pd}$ (range $0.4-7.4 \mathrm{mg} / \mathrm{kg}$ in all samples) and $1.1 \mathrm{mg} / \mathrm{kg} \mathrm{Pt}$ (range $0.3-1.6 \mathrm{mg} / \mathrm{kg}$ ) in $100 \%$ sulfide. In ore samples (Tab. 1), Cu shows linear positive correlations with $\mathrm{Ag}\left(\mathrm{R}^{2}=0.98\right)$, $\mathrm{Au}$ (0.84), Zn (0.65) and Cd (0.96). Ni only shows a weak positive correlation with $\mathrm{Pd}\left(\mathrm{R}^{2}=0.28\right)$, and negative ones with $\mathrm{Sb}(0.50)$ and $\mathrm{Pb}(0.74)$. Co is significantly correlated with As $\left(R^{2}=0.78\right)$ and $\mathrm{Sb}(0.72)$. Zn correlates with $\mathrm{Cd}$ $\left(R^{2}=0.77\right.$; due to $C d$ substitution in sphalerite), and $A g$ with $\mathrm{Au}\left(\mathrm{R}^{2}=0.87\right.$; forming electrum). $\mathrm{Cr}$ is correlated with $M g\left(R^{2}=0.68\right)$ and $V\left(R^{2}=0.63\right)$.

Geochemical classification using major and trace elements of host and country rocks to the Haidbach ore yield a MORB-basaltic chemistry for sulfide-mineralized hornblendite and amphibolite in the hangingwall, whereas the albite-rich gneiss reveals a more intermediate and slightly alkaline composition of basaltic trachyandesite to trachyandesite (Schwabl, 2016). Chondrite-normalized rare earth element (REE) patterns show three different types: the mineralized hornblendites have flat patterns at 2-5 times chondritic REE with negative Eu anomalies (Fig. 5). Albite-chlorite-epidote gneiss (samples HB5, P22) collected underground in the vicinity of sulfide ore 
Table 5. Chemical analyses of Re sulfides from Haidbach. Average composition of tarkianite from Hitura mine for comparison (Kojonen et al., 2004). Formulae calculated on the basis of 13 atoms for tarkianite and 11 atoms for Re-Pb sulfide.

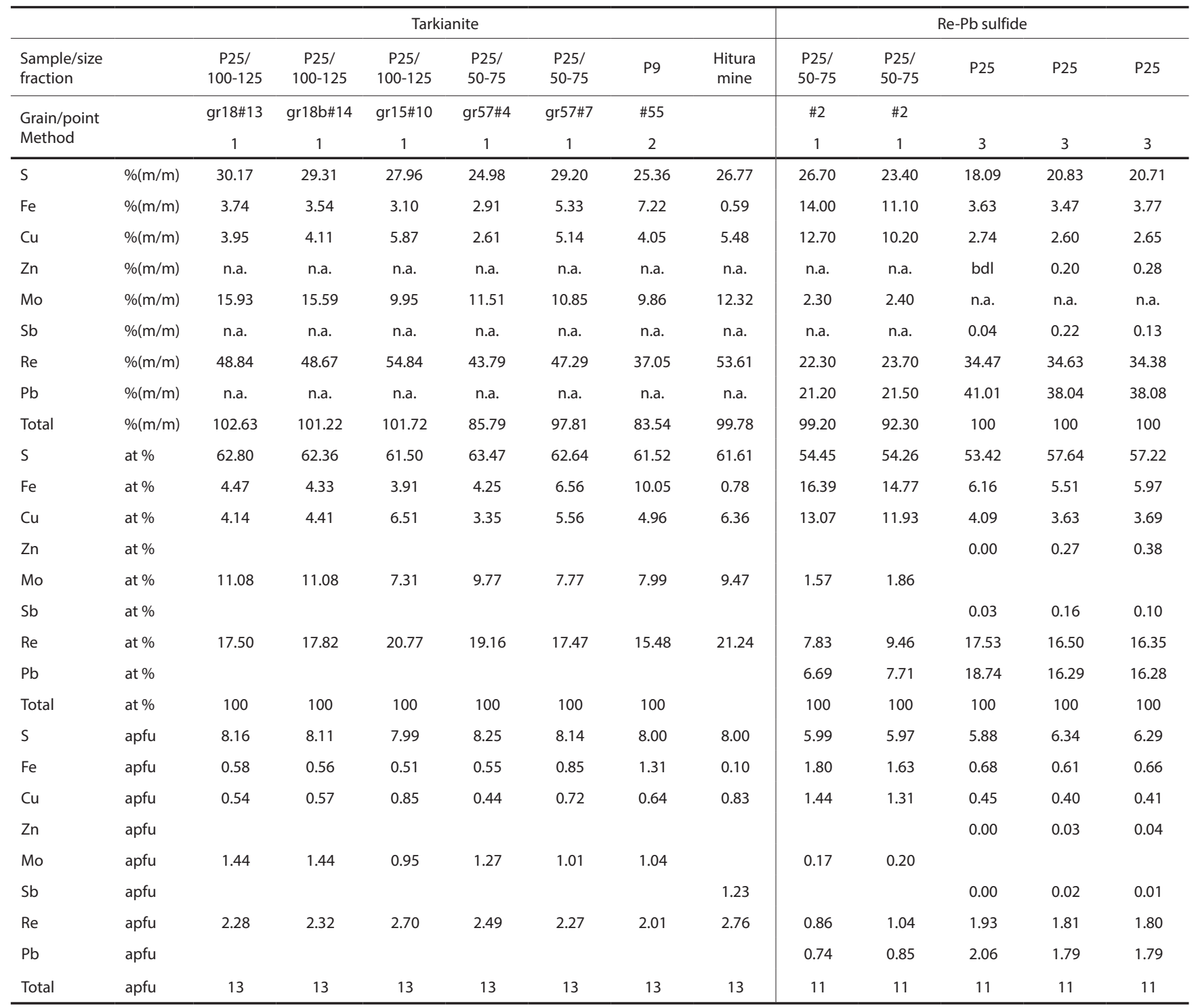

Methods: (1) WD-EMPA MUL; (2) ED-SEM MUL; (3) ED-FEG-EMPA NHM Vienna

Analysis from type locality of tarkianite, Hitura mine, includes $0.09 \% \mathrm{Ni}, 0.08 \% \mathrm{Co}, 0.84 \%$ Os (Kojonen et al., 2004)

apfu, atoms per formula unit: 13 for tarkianite, 11 for Re-Pb sulphide; n.a., not analyzed

yields highly fractionated REE patterns with $>100$ times chondritic light-REE (LREE, La to Sm) and about 10 times chondritic heavy-REE (HREE, Tb to Lu). A third group comprises chlorite schist, amphibolite and gabbro-amphibolite collected outside of the immediate mine area that have slightly LREE-enriched REE patterns (30-70 times chondritic) at 20-30 times chondritic HREE (Fig. 5). Eu anomalies are weak to absent in both groups enriched in the LREE.

\subsection{Mineralogy of the sulfide ore}

\subsubsection{Major $\mathrm{Cu}-\mathrm{Ni}-\mathrm{Fe}$ sulfides}

In the Haidbach $\mathrm{Ni}$-Cu sulfide ore, a more massive ore type (>10\% sulfides) is distinguished from a disseminated ore type (1-10\% sulfides). Pyrrhotite, pyrite, chalcopyrite and pentlandite are the major sulfide minerals in both types (Fig. 3b). According to quantitative analysis of grain mounts from highly mineralized samples produced using the hydroseparation method, Fe sulfides make up about 75 to $92 \%$ of the sulfide assemblage. Chalcopyrite accounts for 1.4 to $19.2 \%$, and pentlandite for 6.3 to $6.8 \%$. Relics of chromian spinel are rarely included in sulfide minerals. Silicates associated with the sulfide ore, mainly amphibole and chlorite, are rich in $\mathrm{Cr}$ and Ni. Whereas pyrite, pyrrhotite and chalcopyrite usually have fresh surfaces, pentlandite is commonly altered to violarite. Despite this, no major alteration is visible in massive ore samples from underground exposures. However, rocks at the mine entrances are severely altered 

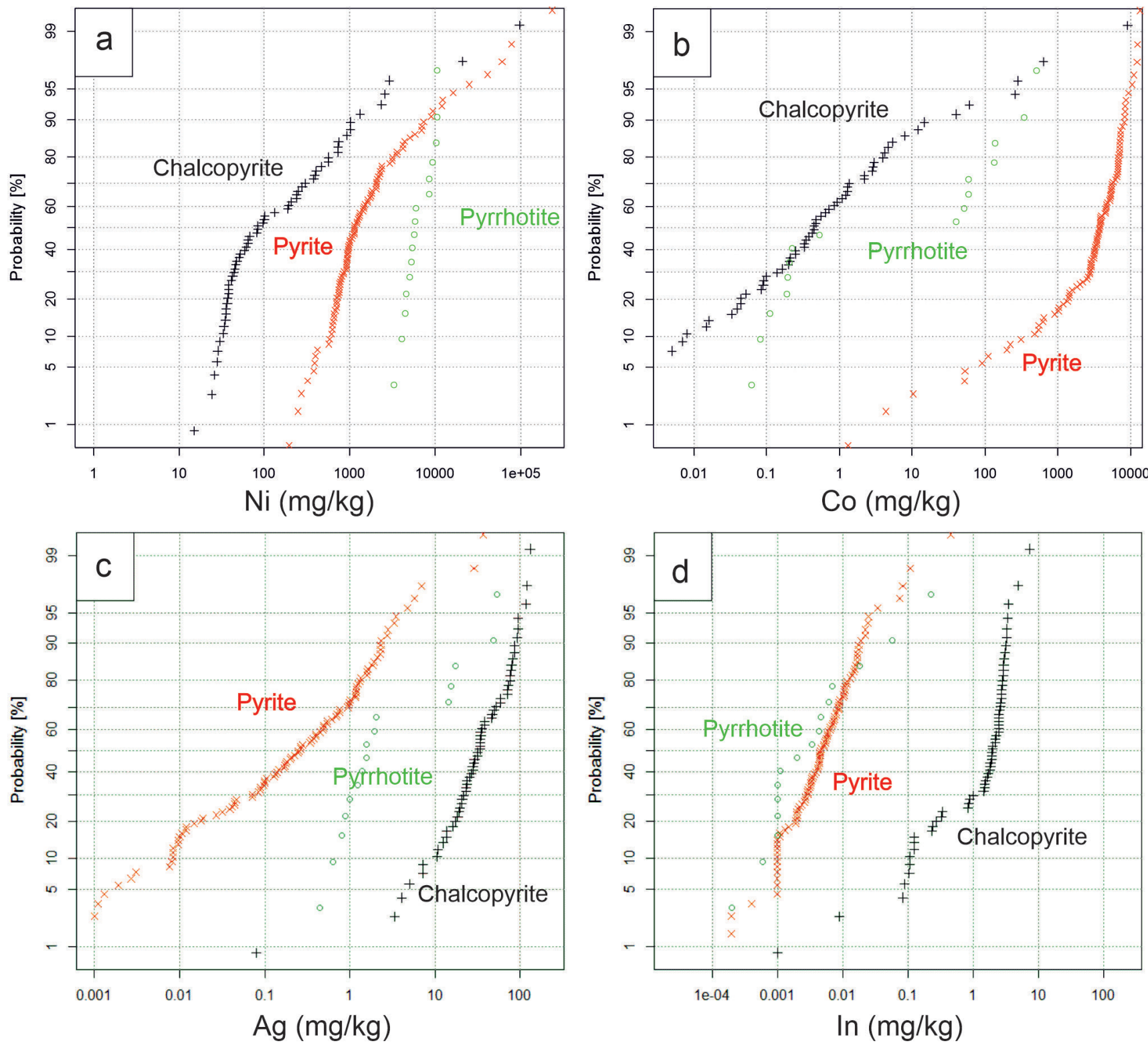

Figure 6. Probability diagrams of $\mathrm{Ni}, \mathrm{Co}, \mathrm{Ag}$ and In in pyrite, pyrrhotite and chalcopyrite from Haidbachgraben, Salzburg.

producing a colourful assemblage of $\mathrm{Ni}-\mathrm{Co}-\mathrm{Cu}$ arsenates and sulfates (e.g., erythrite-annabergite, chalcanthite). Barite and gypsum were encountered in vugs of altered ore close to the mine entrance, suggesting formation during weathering.

The chemical composition of the major sulfides was determined by SEM and LA-ICP-MS (Tab. 2, Fig. 6). Pyrite is the major carrier of Co (median $0.37 \%(\mathrm{~m} / \mathrm{m})$ by LA-ICP-MS) and As (median $0.29 \%(\mathrm{~m} / \mathrm{m})$ ), while $\mathrm{Ni}$ is hosted by pentlandite $(35 \%(\mathrm{~m} / \mathrm{m})$, SEM data) and pyrrhotite (median $0.57 \%(\mathrm{~m} / \mathrm{m}) \mathrm{Ni}$ by LA-ICP-MS). Cobalt concentrations in pentlandite average $0.25 \%(\mathrm{~m} / \mathrm{m})$ (SEM data). $\mathrm{Cu}$ and Fe sulfides all have elevated Se concentrations (maximum of $287 \mathrm{mg} / \mathrm{kg}$ ), with $\mathrm{Se}_{\mathrm{po}}>\mathrm{Se}_{\mathrm{cp}}>\mathrm{Se}_{\mathrm{py}}$. Chalcopyrite hosts significant Zn (median $568 \mathrm{mg} / \mathrm{kg}$ ) and some $\mathrm{Ag}$ (median $34 \mathrm{mg} / \mathrm{kg}$ ), but is low in Sn and In (median 4 and $2 \mathrm{mg} / \mathrm{kg}$, respectively). Co/ $\mathrm{Ni}$ ratios in pyrite average to 3.6 , and in pyrrhotite to 0.005 .
Concentrations of $\mathrm{Au}, \mathrm{Hg}, \mathrm{Ti}, \mathrm{Bi}, \mathrm{Ga}, \mathrm{Ge}, \mathrm{In}$ and $\mathrm{Mo}$ are low in all sulfides. Due to the presence of discrete Re sulfides in some samples, Re was analysed in $\mathrm{Cu}$ and Fe sulfides to confirm if lattice-hosted Re is present to a significant extent. Although no reference material for Re was available, average count rates indicate that Re concentrations in the sulfides must be very low.

\subsubsection{Accessory metal-bearing phases}

The list of accessory minerals identified at Haidbach in unoxidized sulfide ore comprises 28 confirmed and 2 additional (unconfirmed) species (Tabs. 3, 4). Most abundant are $\mathrm{Ni}$-Co-Fe sulfarsenides of the gersdorffite-cobaltite-arsenopyrite solid solution series. Sphalerite is a subordinate phase and occurs as small inclusions mainly associated with chalcopyrite. Iron concentrations are $5-8 \%(\mathrm{~m} / \mathrm{m})$, and substantial $\mathrm{Cd}$ concentrations (>1 $\%(\mathrm{~m} / \mathrm{m})$, up to $2.5 \%(\mathrm{~m} / \mathrm{m})$ ) have been detected 
(Tab. 4, analysis 1). Similar sphalerite compositions are recorded for the disseminated pyrite-chalcopyrite mineralization in the lighter, more massive albite-epidote-chlorite gneiss. Galena is rare and occurs as small inclusions only. It may carry substantial Se concentrations up to $6 \%(\mathrm{~m} / \mathrm{m})$. In several samples, molybdenite flakes of up to $20 \mu \mathrm{m}$ in size were encountered, included in pyrite and chlorite. Scheelite and wolframite are rare accessory phases, but were detected in polished blocks of ore samples as well as in hydroseparation concentrates. Bournonite is rarely found forming rims around base metal sulfides (Tab. 4, analysis 2).

$\mathrm{Ni}$-Co-Fe sulfarsenides of the gersdorffite-cobaltite-arsenopyrite solid solution series commonly form euhedral to subhedral grains at an average size of $8 \times 5 \mu \mathrm{m}$; the largest grain detected measures $100 \times 80 \mu \mathrm{m}$ (Figs. 7a, b; Tab. 4, analyses 3,4$)$. Sulfarsenides occur as inclusions in all base metal sulfides, most commonly in pyrite $(>50 \%$ of the observations) and chalcopyrite (25\%), least common in pentlandite (5\%). In $10 \%$ of the observations $(n=139)$, the sulfarsenides are enclosed in silicates and calcite. Sulfarsenides are rarely associated with other accessory phases such as hessite (Fig. 7b) or Pd-melonite. In the ternary diagram Fe-Ni-Co, the analyses mainly plot into the gersdorffite and cobaltite fields, with some analyses in the arsenopyrite field (Fig. 7c). The compositions range from $\mathrm{XCo}(=100 \times \mathrm{Co} /(\mathrm{Co}+\mathrm{Ni}+\mathrm{Fe})$ in at\%) 0-87 (median 19), XNi 0-85 (median 56) and XFe 0-40 (median 24). Co and Ni are strongly negatively correlated $\left(R^{2}=0.68\right)$, displaying a complete solid solution. Cobalt-rich members are found in few samples only, whereas Ni-rich sulfarsenides are more common. Isotherms plotted into the sulfarsenide diagram of Klemm (1965) point to high-temperature compositions in cobaltite-bearing samples (approximately $600^{\circ} \mathrm{C}$ ); gersdorffite compositions may reflect decreasing temperatures from $600^{\circ} \mathrm{C}$ to $300^{\circ} \mathrm{C}$ (Fig. 6c). Ni-Co-Fe arsenides are extremely rare at Haidbach; a few small anhedral grains of skutterudite have been encountered along pyrite rims (Tab. 4, analysis 5). Lead selenides are rarely associated with pyrrhotine and chalcopyrite. Tiemannite [HgSe] was detected as a single grain in the hydroseparation concentrate of sample P25 (Tab. 3).

Two precious metal assemblages are distinguished based on investigation of both, polished sections from massive and disseminated ores as well as concentrates produced using the hydroseparation method: (1) Ag-Pd$\mathrm{Bi}-\mathrm{Te}-\mathrm{Sb}-(\mathrm{Au})$ association with abundant hessite and various $\mathrm{Pd}$ telluride, bismuthotelluride and Sb-bearing minerals; (2) Re-bearing minerals enclosed in pyrite (Figs. 8, 9). Sperrylite is rarely associated with any of the other precious metal phases. In assemblage (1), hessite $\left[\mathrm{Ag}_{2} \mathrm{Te}\right]$ frequently occurs as subhedral to anhedral grains up to $85 \mu \mathrm{m}$ in size (maximum length; Figs. $8 \mathrm{a}$, 9f). The median grain size is $21 \times 16 \mu \mathrm{m}$. About $50 \%$ of the hessite grains are part of composite inclusions and commonly intergrown with Pd-bearing minerals, gersdorffite and sphalerite. Texturally, many hessite grains were found along grain boundaries of pyrite, chalcopyrite, pentlandite and pyrrhotite; some are also found in the silicate matrix. Chemically, hessite is pure $\mathrm{Ag}_{2} \mathrm{Te}$ with little impurities (Tab. 4, analysis 6), mainly attributed to intergrowth with Pd bismuthotellurides. A few analyses
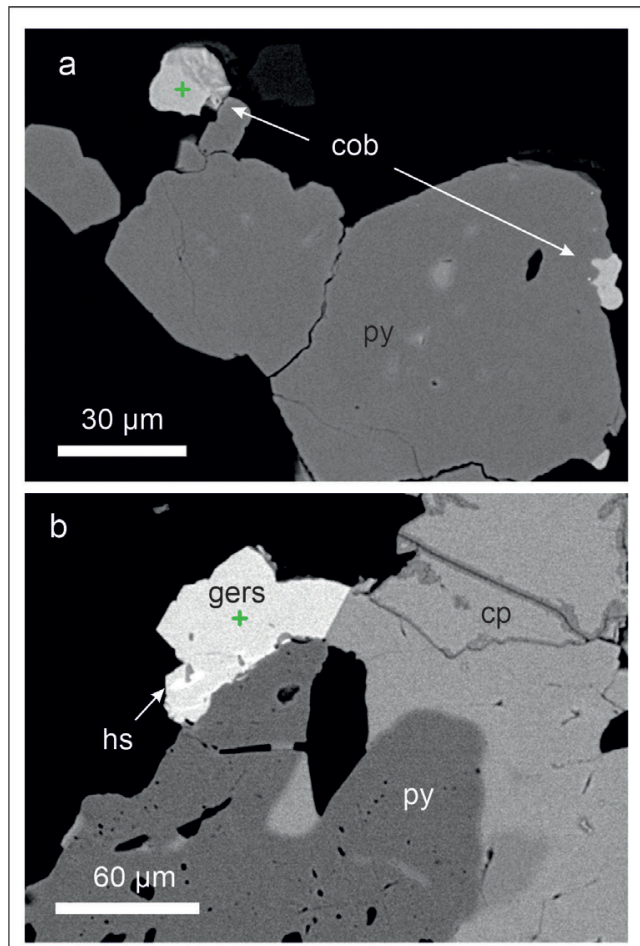

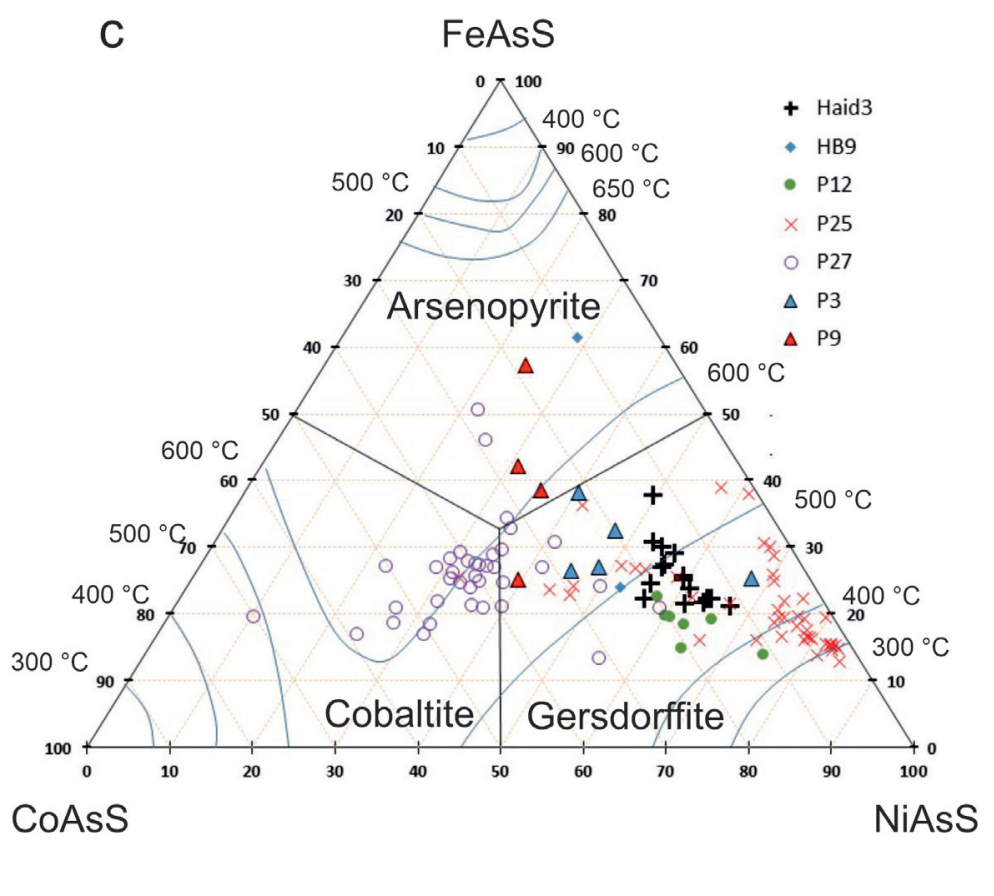

Figure 7. (a) Back-scatter electron image of cobaltite (cob) attached to euhedral pyrite grains, section P27; (b) Gersdorffite (gers) with hessite (hs) inclusion attached to pyrite and chalcopyrite, section Haid3; (c) Triangular diagram of FeAsS - CoAsS - NiAsS calculated from SEM-EDX data of samples from Haidbach; isotherms after Klemm (1965). 
of Ag tellurides point to empressite [AgTe]. However, due to their small grain size and intergrowth with Ni-Pd tellurides the composition is hard to determine.

Electrum (silver-bearing gold) with $13-39 \%(\mathrm{~m} / \mathrm{m}) \mathrm{Ag}$ (median $21 \%(\mathrm{~m} / \mathrm{m})$ ) was mainly detected in the hydroseparation concentrates, reaching up to $80 \times 40 \mu \mathrm{m}$ in size at the median size of $30 \times 15 \mu \mathrm{m}$ (Tab. 4, analysis 7). The electrum grains are usually monomineralic, anhedral, and inclusion-free. Only few of them are associated with petzite, gersdorffite and Pd melonite. Besides $\mathrm{Ag}$ and $\mathrm{Au}, \mathrm{Cu}$ concentrations of up to $3 \%(\mathrm{~m} / \mathrm{m})$ were detected, but usually are below $1 \%(\mathrm{~m} / \mathrm{m})$. PGE concentrations are below the detection limit of the SEM. Few grains of petzite $\left[\mathrm{Ag}_{3} \mathrm{AuTe}_{2}\right]$ were found in the hydroseparation concentrates, intergrown with sudburyite, hessite, Pd-melonite, and electrum (Ag 13-16 \%(m/m)) (Fig. 9c; Tab. 4, analysis 8). Argentopentlandite forms rare, small inclusions in pentlandite and pyrrhotite (Fig. 9b). In the hydroseparation concentrates, it is also associated with hessite and $\mathrm{Pd}$ bismuthotellurides. The largest grain, measuring $>70 \mu \mathrm{m}$ in length and $20 \mu \mathrm{m}$ in width, forms an euhedral inclusion in pyrite and is rimmed by $\mathrm{Ag}$-free pentlandite. Ag concentrations range from 9-14\%(m/m); the average formula calculated from 8 EDX analyses is $\left(\mathrm{Ni}_{5.2} \mathrm{Fe}_{3.1} \mathrm{Ag}_{0.9}\right)_{9.2} \mathrm{~S}_{7.8}$. Cobalt concentrations in argentopentlandite are $0.2 \%(\mathrm{~m} / \mathrm{m})$ on average (Tab. 4 , analysis 9). Argentite/acanthite $\left[\mathrm{Ag}_{2} \mathrm{~S}\right]$ was encountered attached to base metal sulfides or enclosed by altered pentlandite (Tab. 4, analysis 10).

Sperrylite is the only primary Pt phase observed. It is unrelated to type (1) and (2) precious metal assemblages and commonly forms euhedral and solitary crystals of up to $80 \times 40 \mu \mathrm{m}$ size (Fig. 9a). Sperrylite is chemically rather pure (up to $1 \%(\mathrm{~m} / \mathrm{m}) \mathrm{Sb},<0.5 \%(\mathrm{~m} / \mathrm{m})$ Pd; Tab. 4, analysis 11 ) and is the only PGM that was found more than occasionally in silicate matrix, outlining its resistance to metamorphic decomposition. Hydrothermal alteration processes lead to the formation of tetraferroplatinum [PtFe] and Fe-bearing platinum that were both found in cracks of altered host sulfides. A few small grains $(<5 \mu \mathrm{m})$ of Ir-(Pt,Rh) sulfarsenide were encountered, either forming solitary inclusions in Fe sulfide, or forming clusters of grains in silicate matrix (Fig. 9d). Due to the high Ir content, the phases represent irarsite (>80 mol\% IrAsS component). Rh, Os and Pt were detected in variable amounts (Tab. 4, analysis 12).

Palladium-rich tellurides (palladian melonite, merenskyite, sudburyite, kotulskite, keithconnite), bismuthotellurides and $\mathrm{Sb}$-rich bismuthotellurides (michenerite, testibiopalladite) are abundant, forming small grains commonly included in hessite and gersdorffite in type (1) assemblages (Figs. 8a, 9, 10; Tab. 4, analyses 13-20). Palladian melonite $\left[(\mathrm{Ni}, \mathrm{Pd}) \mathrm{Te}_{2}\right]$ is the most common Pd-bearing phase at Haidbach with more than 150 grains documented, found as euhedral, anhedral or subhedral grains up to $90 \mu \mathrm{m}$ in size (Tab. 4, analysis 13). They are commonly hosted by pyrite and chalcopyrite and often intergrown with hessite (Figs. 9c, e). The average composition is $\left[\left(\mathrm{Ni}_{07} \mathrm{Pd}_{03}\right) \mathrm{Te}_{2}\right]$, but compositions are highly variable and range from $0.5-1.0$ apfu (calculated for 3 atoms) $\mathrm{Ni}$, 0.05-0.48 apfu Pd, 1.7-2.0 apfu Te, up to 0.2 apfu Sb and $0.14 \mathrm{apfu} \mathrm{Bi}$. The more Bi-rich analyses may correspond to "bismuthian palladian melonite", the Sb-rich ones may be referred to as "antimonian palladian melonite". Compositions are illustrated in a ternary $\mathrm{Ni}-\mathrm{Pd}-(\mathrm{Te}+\mathrm{Sb}+\mathrm{Bi})$ diagram (Fig. 11a), demonstrating a complete solid solution with merenskyite $\left[\mathrm{PdTe}_{2}\right]$. In this system, $\mathrm{Pd} /(\mathrm{Te}+\mathrm{Sb}+\mathrm{Bi})$ values in the intermediate phase $\mathrm{Pd}$-melonite range from 0.1 to 0.3 with Ni/Pd $>0.5$, whereas merenskyite has $\mathrm{Ni} / \mathrm{Pd}$ $<0.5$ (Tab. 4, analysis 14). In both melonite and merenskyite, $\mathrm{Te}$ is the dominant semimetal, with $\mathrm{Te} /(\mathrm{Te}+\mathrm{Sb}+\mathrm{Bi})$ $>0.7$. The contributions of $\mathrm{Sb}$ and $\mathrm{Bi}$ may reach 0.2 and

\section{Hessite - Pd telluride association}

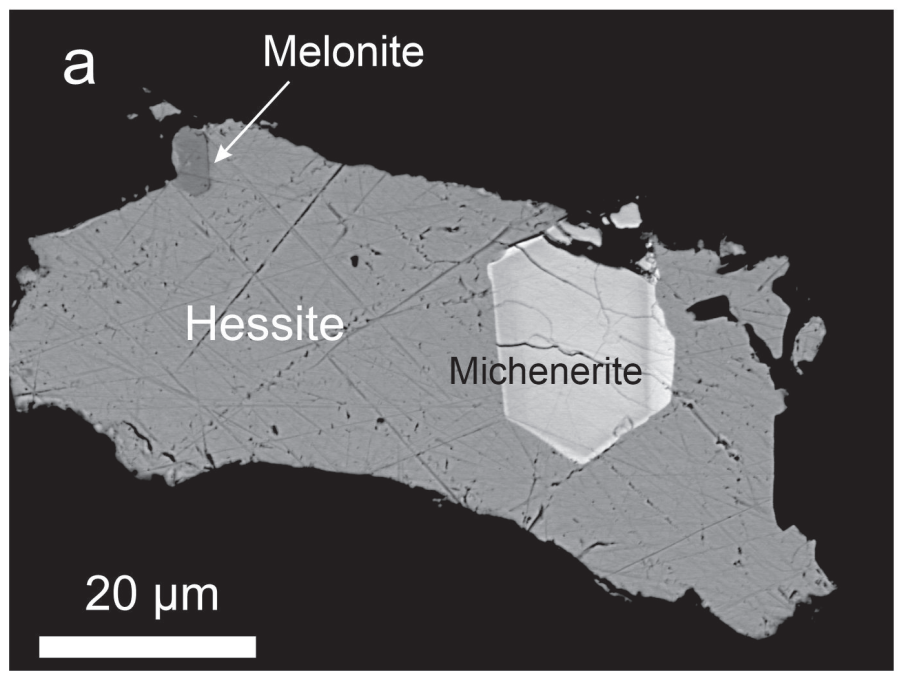

Pyrite - Re sulfide association

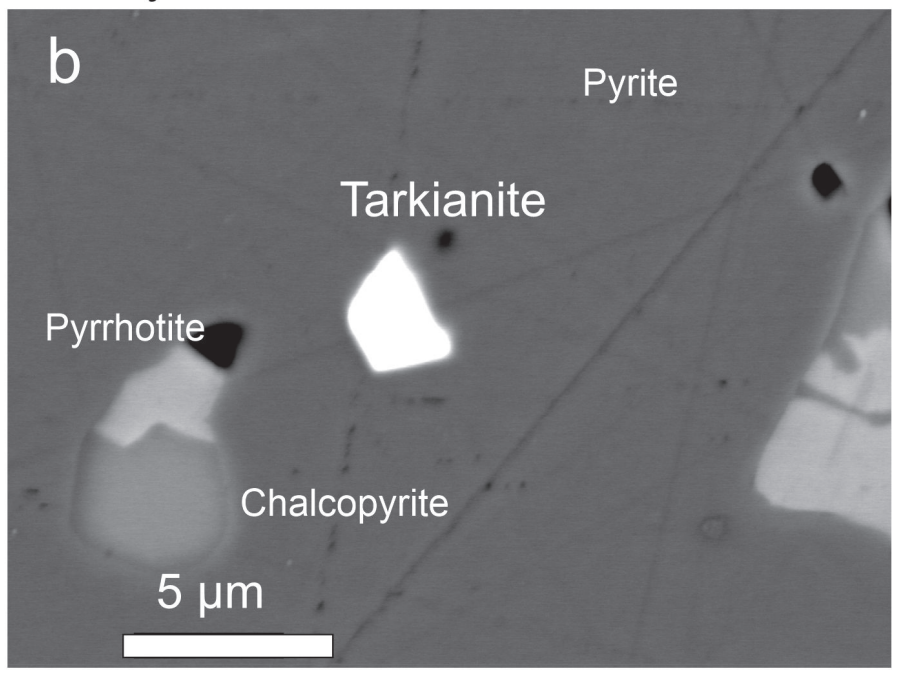

Figure 8. Back-scatter electron images (FEG-EMPA) of typical precious metal assemblages in sulfide ores at Haidbach. (a) Hessite, michenerite and melonite; michenerite is more Sb-rich in the core $\left(\mathrm{PdTe}\left(\mathrm{Bi}_{0.6} \mathrm{Sb}_{0.4}\right)\right)$ and more Bi-rich in the brighter rim $\left(\mathrm{PdTe}\left(\mathrm{Bi}_{0.8} \mathrm{Sb} \mathrm{b}_{0.2}\right)\right)$; $\mathrm{HS}$ concentrate $\mathrm{P} 12 \_30-50 ;(b)$ Tarkianite included in pyrite with melt inclusions of pyrrhotite and chalcopyrite; section P9. 

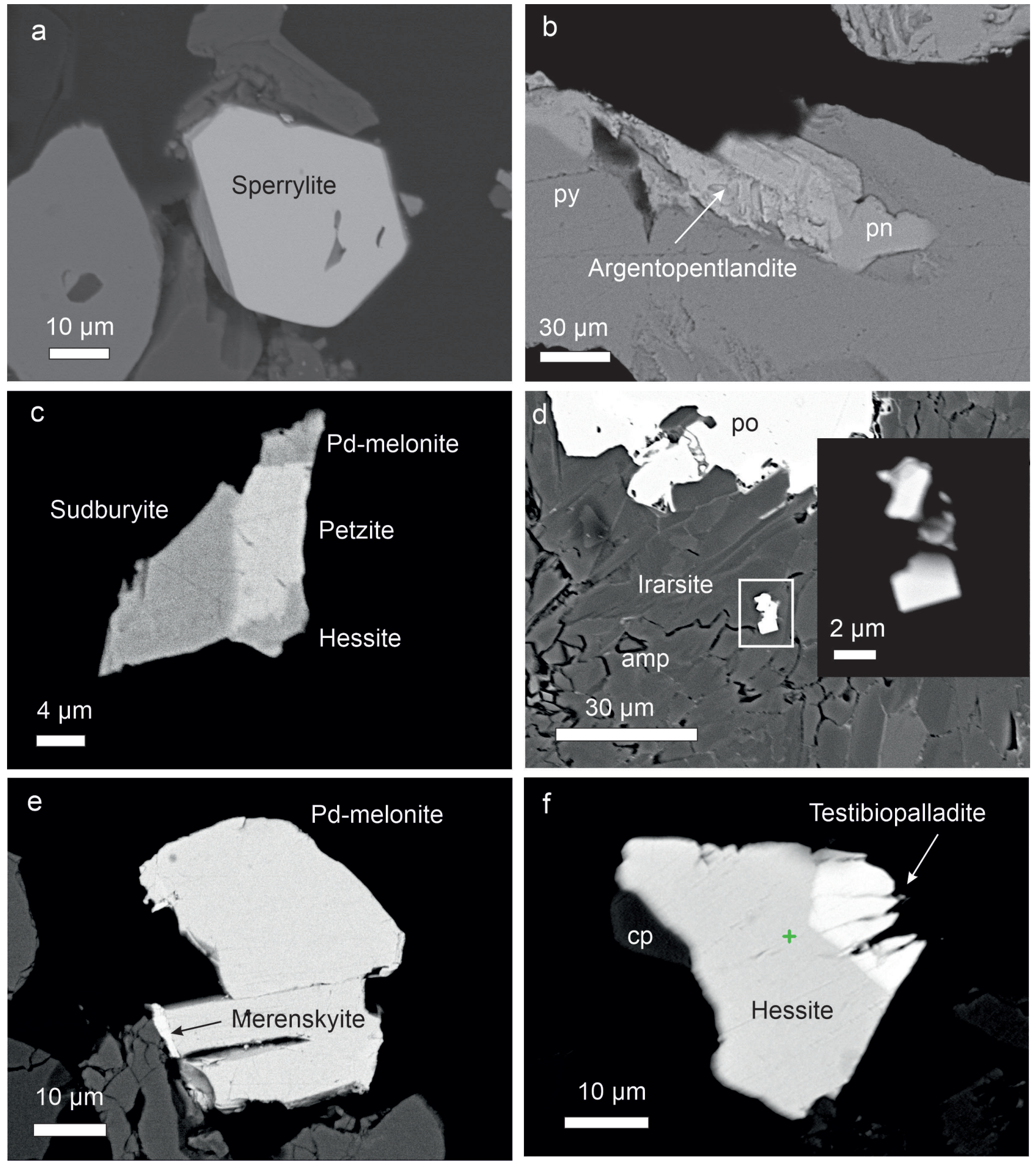

Figure 9. Back-scatter electron images of precious metal inclusions in sulfide ores at Haidbach. (a) Sperrylite, HS concentrate P12_30B; (b) Argentopentlandite enclosed by pentlandite (pn) and pyrite (py), HS concentrate P25_100-125; (c) Assemblage of petzite, sudburyite, Pd-melonite and hessite, HS concentrate P12_30B; (d) Cluster of irarsite crystals in silicate matrix (inset at higher magnification and higher contrast), section P9; (e) Pd-melonite with attached merenskyite, HS concentrate P12_30B; (f) Assemblage of chalcopyrite (cp), hessite and testibiopalladite or Sb-bearing michenerite, HS concentrate P12_30-50A.

0.4 apfu, respectively. In the concentrates, the largest merenskyite grain measures $53 \times 38 \mu \mathrm{m}$ in size (Fig. 10). Compositions are furthermore illustrated in a ternary $\mathrm{PdTe}_{2}-\mathrm{PdBi}_{2}-\mathrm{PdSb}_{2}$ diagram (Fig. 11b), outlining solid solutions towards michenerite and testibiopalladite. Platinum concentrations are mostly below the detection limit of the EDX system, with maximum values of $3 \%(\mathrm{~m} / \mathrm{m}) \mathrm{Pt}$.

Michenerite $[\mathrm{PdTe}(\mathrm{Bi}, \mathrm{Sb})]$ carries substantial $\mathrm{Sb}$ and/or $\mathrm{Bi}$ $(\Sigma \mathrm{Bi}+\mathrm{Sb}=1 \mathrm{apfu})$ and Te concentrations close to $1 \mathrm{apfu}$, calculated for a total of 3 atoms (Fig. 8a). Similar to 
merenskyite, Pt concentrations are very low. A solid solution between michenerite-(Sb) and michenerite-(Bi) is evident (Fig. 11b; Tab. 4, analysis 15, 16). Some analyses of Pd-rich tellurides have $\mathrm{Te}>1.0$, but considerable $\mathrm{Sb}$ and little $\mathrm{Bi}$. Such phases likely represent testibiopalladite [PdTe(Te,Sb)] (Figs. 9f, 11b; Tab. 4, analysis 17). At the Bi-rich side of the diagram, an analogous phase of $[\mathrm{PdTe}(\mathrm{Te}, \mathrm{Bi})]$ composition was observed (Fig. 11b). Merenskyite, michenerite and testiobiopalladite are members of the cobaltite group and obviously form complete solid solution series.

Sudburyite [PdSb] is rare and is either associated with petzite and Pd-melonite (Fig. 9c), or is a late-stage crack-filling phase in Fe and Cu sulfides (Tab. 4, analysis 18). A small grain of a Pd telluride of $\left[\mathrm{Pd}\left(\mathrm{Te}_{0.8} \mathrm{Bi}_{0.2}\right)\right]$ composition located at the rim of a pyrite grain probably represents kotulskite (Tab. 4, analysis 19). A single grain, $4 \mu \mathrm{m}$ in size, of $\left.\left[\mathrm{Pd}_{20} \mathrm{Te}_{7}\right)\right]$ composition at a chalcopyrite-pyrite contact carries appreciable Sb $(4.5 \%(\mathrm{~m} / \mathrm{m}))$ and $\mathrm{Bi}(7.5 \%(\mathrm{~m} / \mathrm{m}))$ (Tab. 4, analysis 20$)$; the stoichiometry fits to keithconnite [originally defined as $\mathrm{Pd}_{3-\mathrm{x}} \mathrm{Te}$; Cabri et al., 1979].

Rhenium-rich sulfides have been encountered in a few polished blocks of type (2) assemblages (Tab. 3; Fig. 8b). At least two different Re phases are distinguished: Euhedral single grains, less than $10 \mu \mathrm{m}$ in size, of a Cu-Fe-Re-Mo sulfide included in pyrite are identified as tarkianite $\left[(\mathrm{Cu}, \mathrm{Fe})(\mathrm{Re}, \mathrm{Mo})_{4} \mathrm{~S}_{8}\right]$, a cubic phase characterized by high hardness crystallizing in the linnaeite group (Figs. 8b, 12) (Kojonen et al., 2004). Consistent concentrations of Fe and $\mathrm{Cu}$ indicate that these elements are present in the lattice, despite possible contribution from host pyrite. The presence of Mo in the mineral is verified by wavelength-dispersive scans and analyses (Tab. 5, Fig. 13). Only one tarkianite grain was observed included in pentlandite (concentrate P25), while most are enclosed by pyrite or were found along pyrite/chalcopyrite contacts (Fig. 12). Melt inclusions of chalcopyrite, pentlandite and pyrrhotite in pyrite are occasionally associated with tarkianite (Figs. 8b, 12e). Tarkianite is a very rare mineral and described here for the first time in central Europe.

A second Re sulfide forms small, deformed laths $(<2 \mu \mathrm{m}$ thick) similar in appearance to molybdenite. This Re phase usually decorates chalcopyrite rims or grain boundaries (Fig. 14a), or is included in chalcopyrite (Fig. 14b). X-ray maps and wavelength-dispersive element scans indicate the presence of $\mathrm{S}, \mathrm{Pb}, \mathrm{Re}$, some Mo and probably some Fe and Cu (Tab. 5; Fig. 14b). The stoichiometry based on EMPA analyses is close to ( $\mathrm{Re}, \mathrm{Pb}, \mathrm{Mo}, \mathrm{Cu}, \mathrm{Fe})_{5} \mathrm{~S}_{6}$. If possible contributions of $\mathrm{Fe}, \mathrm{Cu}$ and $\mathrm{S}$ from the host chalcopyrite grains are subtracted, an approximate composition of $\mathrm{RePbS}_{3}$ is obtained. This Re phase is either a new mineral, or a Cu-free and Mo-poor variety of dzhezkazghanite $\left[\mathrm{ReMoCu}_{2} \mathrm{PbS}_{6}\right]$. Dzhezkazghanite is a trigonal phase with a structure similar to molybdenite-3R (Genkin et al., 1994) that was, however, discredited by the IMA due to incomplete data.
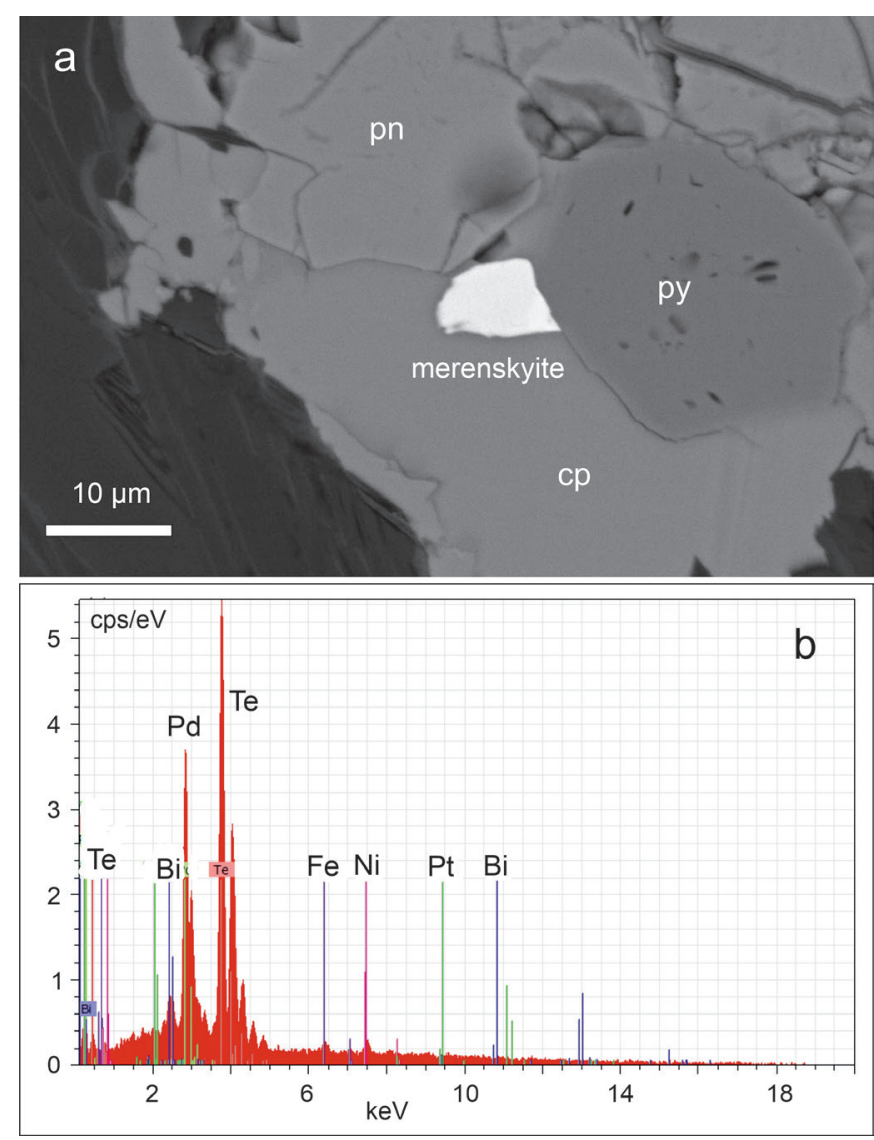

Figure 10. (a) Back-scatter electron image of merenskyite associated with pentlandite, pyrite and chalcopyrite, section HB9; (b) EDX spectrum of merenskyite, $\left(\mathrm{Pd}_{0.9} \mathrm{Ni}_{0.1}\right) \mathrm{Te}_{2}$.

\section{Discussion}

\subsection{Genetic model for the Haidbach Cu-Ni-Co-PGE mineralization}

The Haidbach ore type appears unique in the Subpenninic Venediger Nappe System of the Eastern Alps. The ore mineral assemblage is truly polymetallic, containing minerals of six precious metals ( $\mathrm{Au}, \mathrm{Ag}, \mathrm{Pd}, \mathrm{Pt}, \mathrm{Ir}, \mathrm{Re}$ ) and five semimetals ( $\mathrm{As}, \mathrm{Sb}, \mathrm{Bi}, \mathrm{Te}, \mathrm{Se}$ ) associated with the base metals $\mathrm{Cu}, \mathrm{Ni}, \mathrm{Co}$ and Fe. Based on mineralogy, two assemblages can be distinguished: (1) a pyrrhotite-pentlandite-chalcopyrite-pyrite assemblage with abundant $\mathrm{Pd}$ and Ag tellurides (Fig. 8a), and (2) a pyrite-(chalcopyrite-pyrrhotite-pentlandite) assemblage with Re sulfides (Fig. 8b). Native gold is more abundant in the type (1) assemblage that has frequent $\mathrm{Pd}$ tellurides associated with hessite and a variable $\mathrm{Ni}-\mathrm{Co}-\mathrm{Fe}$ sulfarsenide chemistry. In contrast, type (2) assemblage is poor in Pd minerals. Pd-melonite is more Ni-rich, and gersdorffite is Co-poor. Rounded polyphase sulfide droplets containing combinations of pyrrhotite, chalcopyrite, pentlandite and precious metal minerals are included in recrystallized sulfide, mainly in pyrite (Figs. $4 d, 8 b, 12 d$ ). These textures 


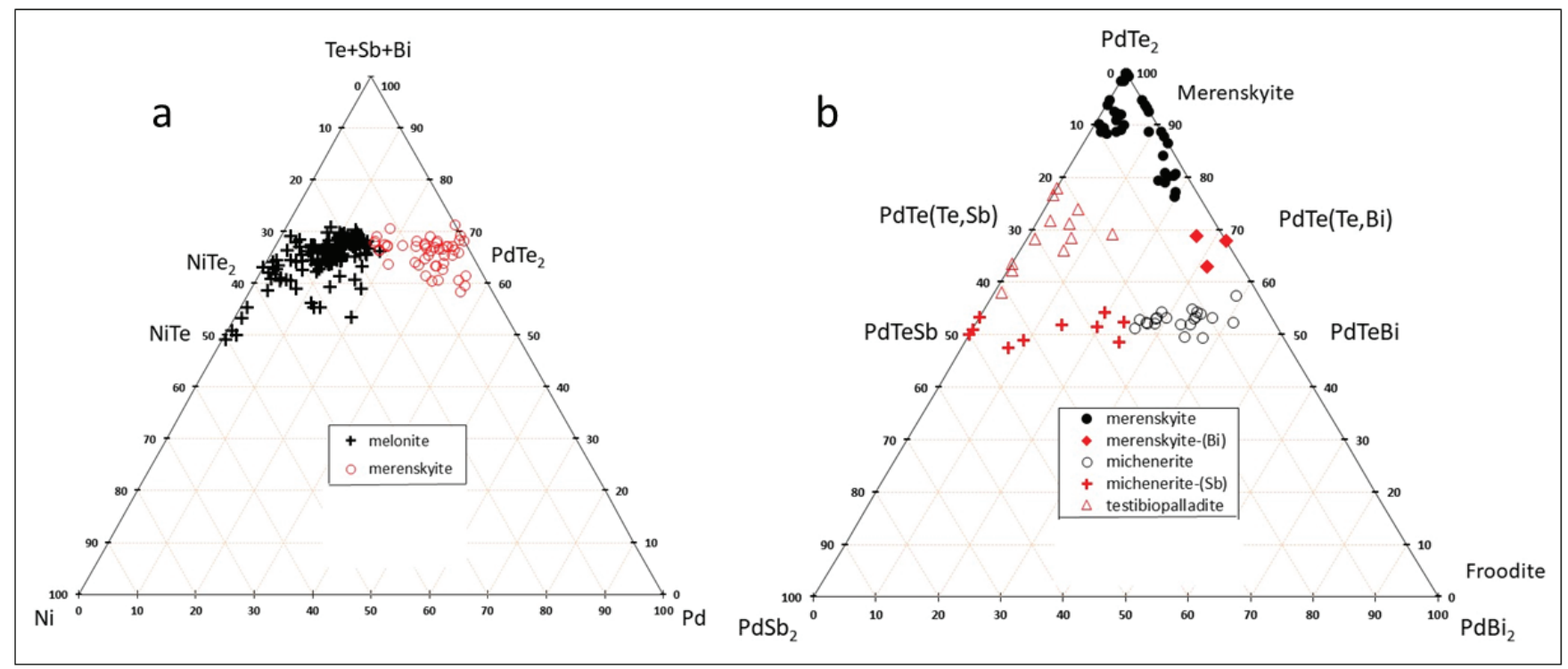

Figure 11. Triangular diagrams for some Ni-Pd-Te-Bi phases of $\mathrm{M} / \mathrm{SM}=0.5$ stoichiometry ( $\mathrm{M}$, metals; $\mathrm{SM}$, semimetals); (a) Ni, $\mathrm{Pd}$ and Te+Sb+Bi (atomic \%); (b) $\mathrm{PdTe}_{2}, \mathrm{PdSb}_{2}, \mathrm{PdBi}_{2}$ (atomic \%); SEM-EDX data.

are indicative of a magmatic origin of the ore. Sperrylite is rarely associated with precious metal phases (such as hessite, testibiopalladite) and is not only restricted to the base metal sulfides, but also occurs in the metamorphic silicate matrix. It is the most stable PGM in the assemblage under metamorphic, hydrothermal and weathering conditions and thus may constitute a relict magmatic phase formed at high temperature upon cooling from a sulfide-arsenide-telluride system (Helmy et al., 2013). The polyphase, rather complex $\mathrm{Pd}-\mathrm{Ag}$-Te-Bi-Sb assemblage likely represents a late product of equilibration and recrystallization. Helmy et al. (2007) have experimentally investigated the Pd-Pt-Ni-Te-S system and concluded that natural $\mathrm{Pd}-\mathrm{Pt}$ bismuthotellurides do not provide meaningful temperature information. The effects of $\mathrm{Bi}$ and $\mathrm{Sb}$ substitution have not been experimentally covered. However, it is inferred that low-temperature Te exsolution from sulfides is instrumental for the variety of phase compositions observed in nature. This exsolution may take place when a low-temperature pyrrhotite-pentlandite-chalcopyrite-pyrite assemblage crystallizes from monosulfide and intermediate sulfide solid solution precursor phases at temperatures well below $300{ }^{\circ} \mathrm{C}$. This excludes that the $\mathrm{Pd}-\mathrm{Te}-\mathrm{Sb}-\mathrm{Bi}$ phases at Haidbach are magmatic phases. In contrast, Co-Ni-Fe sulfarsenides which are moderately abundant phases in the ore partly record higher temperatures, reaching more than $600{ }^{\circ} \mathrm{C}$ using the isotherms constructed by Klemm (1965) based on lattice parameters (Fig. 7c). Such temperatures are also in agreement with the presence of pargasitic amphibole relics in mineralized hornblendite (Fig. 3, 4a, 4b), and thus clearly exceed temperature conditions reached during the Neoalpine metamorphic event $\left(<450{ }^{\circ} \mathrm{C}\right.$; Schuster et al., 2004; Gross et al., 2020). Evidence from textures and mineral compositions thus indicates local preservation of pre-Alpine conditions at Haidbach.
The presence of discrete Re minerals in the ore is a result of elevated Re (Tab. 1). However, the scarcity of Re minerals in most orthomagmatic Ni-Cu-(PGE) sulfide ores, despite elevated Re concentrations, indicates that $R e$ is commonly fixed in solid solution in base metal sulfides instead of forming discrete phases. Recrystallization of sulfides during metamorphism might then be responsible for exsolution of Re to form Re sulfides. In the Haidbach deposit, pyrrhotite presumably was the major host of $\operatorname{Re}$ (Tab. 2). During sulfidation of pyrrhotite to pyrite, Re was liberated forming tarkianite that is almost invariably hosted by pyrite (Fig. 12). The much less abundant $\mathrm{Pb}-\mathrm{Re}$ sulfide, on the other hand, is hosted by chalcopyrite (Fig. 14). An external source of elements such as Re, Mo (hosted by molybdenite and tarkianite) and W (hosted by subordinate scheelite and wolframite) cannot be excluded at Haidbach, because Variscan granites intruded into the Early Palaeozoic ophiolite complex further to the south. The degree of metasomatism surrounding the intrusions is unknown, but appears to be of relevance (Niedermayr and Schroll, 1983). The presence of very minor scheelite in the Haidbach ore might point to this metasomatic effect. In the Felbertal tungsten deposit, scheelite is associated with molybdenite that may serve, if mobilized by hydrothermal fluids, as a local candidate for Re supply. Molybdenite is a common host of Re; $3-20 \mathrm{mg} / \mathrm{kg}$ Re are reported from molybdenite at the Felbertal deposit (Raith and Stein, 2006).

The hornblendite hosting the $\mathrm{Ni}-\mathrm{Cu}-\mathrm{Co}-\mathrm{PGE}$ sulfide ore is characterized by high $\mathrm{MgO}$ and $\mathrm{Cr}$, and low $\mathrm{SiO}_{2}$, $\mathrm{Al}_{2} \mathrm{O}_{3}$ and alkali metals (Tab. 1). Chondrite-normalized REE patterns of hornblendites are flat at 2-5 times chondritic REE (Fig. 5), indicating a probable derivation from mafic mantle melts. REE patterns of hornblendites differ from REE patterns of non-mineralized country rocks that are slightly (i.e., amphibolites north of the mine) or 

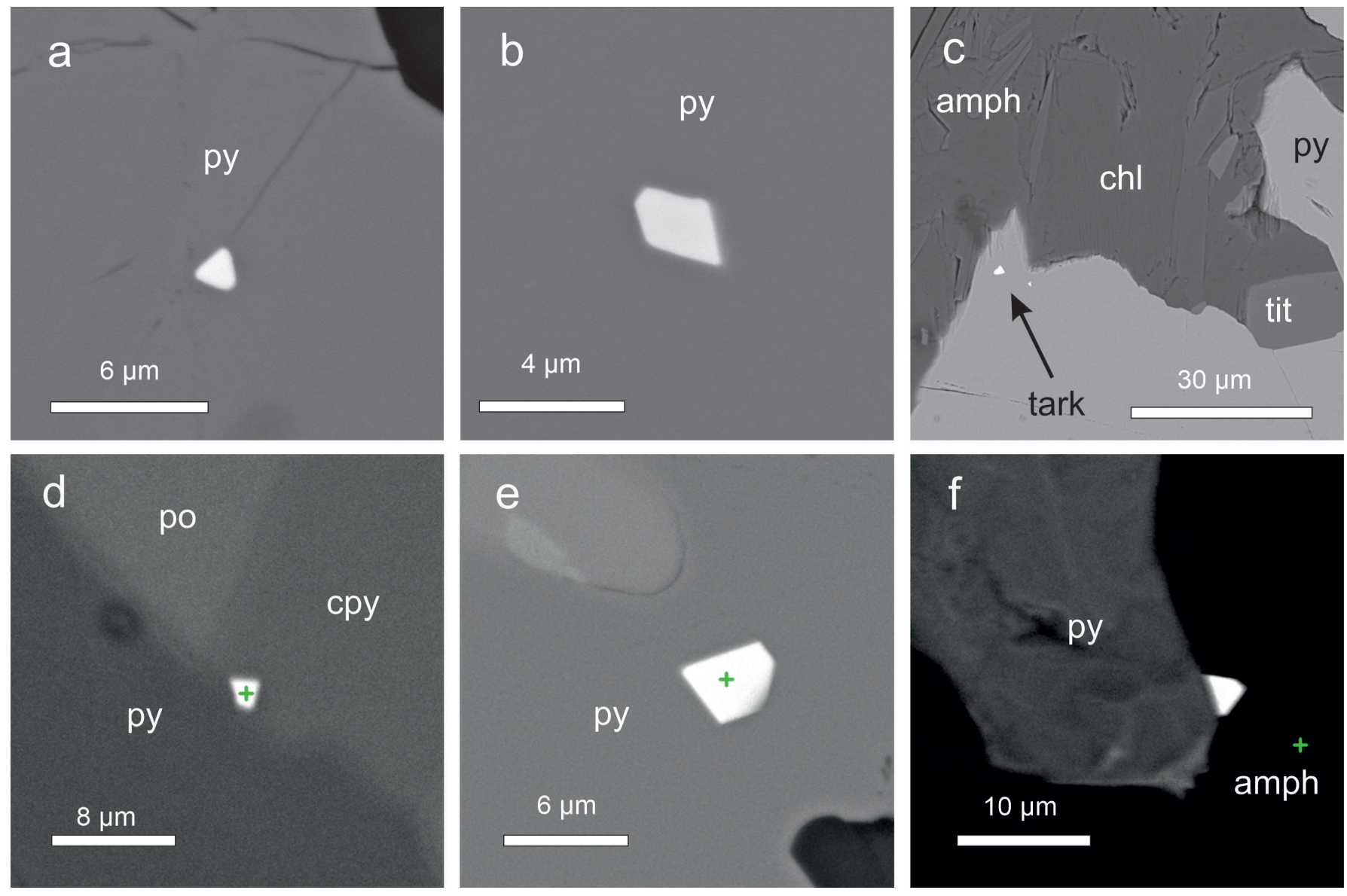

Figure 12. Back-scatter electron images of tarkianite (brightest phase) included in sulfides and silicates; (a) tarkianite included in pyrite, section P9; (b) tarkianite included in pyrite, section P9; (c) tarkianite (arrow) included in pyrite close to contact with chlorite, amphibole and titanite (tit), section P13; (d) tarkianite at pyrite/chalcopyrite contact, section P27; (e) tarkianite included in pyrite adjacent to sulfide melt inclusion, section P25; (f) tarkianite attached to pyrite in contact with amphibole (amph), section P13.

heavily (i.e., albite-epidote-chlorite gneiss within the mine area) enriched in LREE at overall higher REE totals (Fig. 5), indicating a calc-alkaline character of the parent rocks. REE patterns of hornblendite resemble those reported from serpentinite at Hintersee in the Felber valley (Melcher et al., 2002; Fig. 5). The serpentinites represent metamorphosed and metasomatized harzburgites in an Early Palaeozoic ophiolite sequence with midocean ridge basalt signature formed in a back-arc basin (Melcher et al., 2002). REE patterns along with low Si, Al, alkalis, and high $\mathrm{Mg}, \mathrm{Ca}$ and $\mathrm{Cr}$ suggest that the hornblendites hosting the Haidbach sulfide ore are related to these serpentinites. They might have formed as mafic pyroxenite veins intruded into oceanic crust and were metamorphosed to hornblendite during the Variscan metamorphic event. Ultramafic rocks of similar composition, mostly metapyroxenites and minor serpentinized harzburgites, are reported from the "basal amphibolite" at Stubach valley (Fig. 1; Petrakakis, 1977, 1978; Melcher et al., 2002).

\subsection{Sulfide deposits in Palaeozoic rocks of the Venediger Nappe System}

Based on structure, texture, host rock, mineralogical composition and trace elements in major sulfides (chalcopyrite, pyrite, pyrrhotite, sphalerite; Melcher and Onuk, 2019a, b), ore accumulations in the Subpenninic Nappe System of the Tauern Window are grouped into (i) orthomagmatic Ni-Cu-Co-PGE sulfide deposits (Haidbach), (ii) stratiform massive sulfide deposits (Hochfeld, Brenntal, Sprinzgasse), (iii) vein-type deposits (Achselalpe) and (iv) stockwork-type/impregnation/disseminated deposits (Felbertal W deposit) (Appendix 1). Orthomagmatic and stratiform deposits likely formed prior to the Variscan and Alpine orogenic events and probably represent metal accumulations syngenetic with their host rocks. The Felbertal W deposit is clearly associated with Variscan granite intrusions. Among the veintype deposits, the Au-bearing sulfide-quartz veins within the "Gold ore district Venediger Nappe System (Rauris Gastein Tauern gold veins)" (Fig. 1) are the youngest (27 Ma; Paar, 2000), whereas others (e.g. Achselalpe) are of unclear age. Similarities in mineralogy, e.g. the presence of Te and Bi minerals as well as complex sulfosalts in many of the occurrences, may be explained by a common Neoalpine overprint, because most of these phases have limited temperature stability fields. The presence of native electrum at Haidbach and other stratiform ores (Hochfeld) is of interest in the light of a discussion about the sources of gold in the Tauern gold veins. 

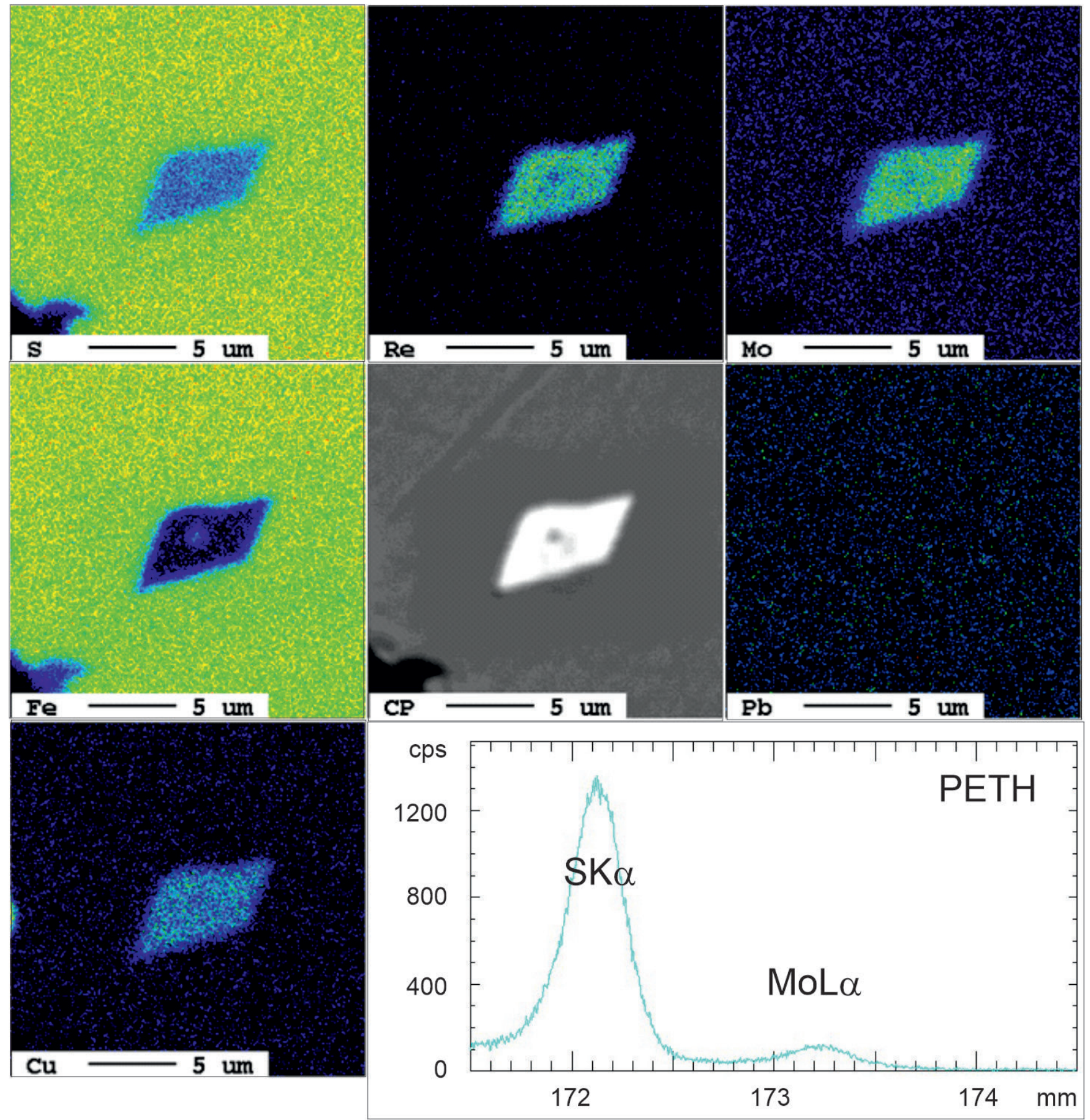

Figure 13. BSE image, and wavelength-dispersive $\mathrm{X}$-ray element maps of $\mathrm{S}, \mathrm{Re}, \mathrm{Mo}, \mathrm{Fe}, \mathrm{Pb}$ and $\mathrm{Cu}$ in tarkianite enclosed by pyrite, and spectral scans of SKa and MoLa lines in tarkianite. Hydroseparation concentrate P25, fraction 50-75 $\mu \mathrm{m}$.

With regards to the host rock and main ore minerals, the former Hochfeld deposit in the Untersulzbach valley (Fig. 1, Appendix 1) appears closest to Haidbach. It is hosted by biotite-chlorite schist enclosed by albite gneiss, muscovite quartzite and muscovite-chlorite schist of the Peitingalm Complex, and contains pyrite (10-70\% of the ore), chalcopyrite (10-60\%) and pyrrhotite (5-30\%) as well as minor sphalerite (6-12\% Fe) and galena. Ore samples also carry accessory native Au-Ag alloy (up to $25 \% \mathrm{Ag}$ ), bismuth, tellurides (altaite, hessite, stützite, tellurobismuthite), sulfosalts and glaucodote
(Grundmann et al., 1990; Seemann et al., 1993; Lerch et al., 2009). Ore concentrate samples yield 0.1-0.2 mg/kg Au, 20-70 mg/kg Ag and 10-90 mg/kg Te, and up to $90 \mathrm{mg} / \mathrm{kg}$ $\mathrm{Bi}$ and $50 \mathrm{mg} / \mathrm{kg} \mathrm{Se}$. However, Ni minerals have not been reported from Hochfeld, and PGE analyses are not available. Telluride-bearing assemblages have also been documented from an ore paragenesis similar to Hochfeld at Blauwandlstollen/Knappenwand (Seemann and Brandstätter, 1987), with altaite forming rounded grains up to $0.1 \mathrm{~mm}$ in size. The ore is hosted by biotite-chlorite schist, with local garnet porphyroblasts up to $3 \mathrm{~cm}$ in size. ICP 


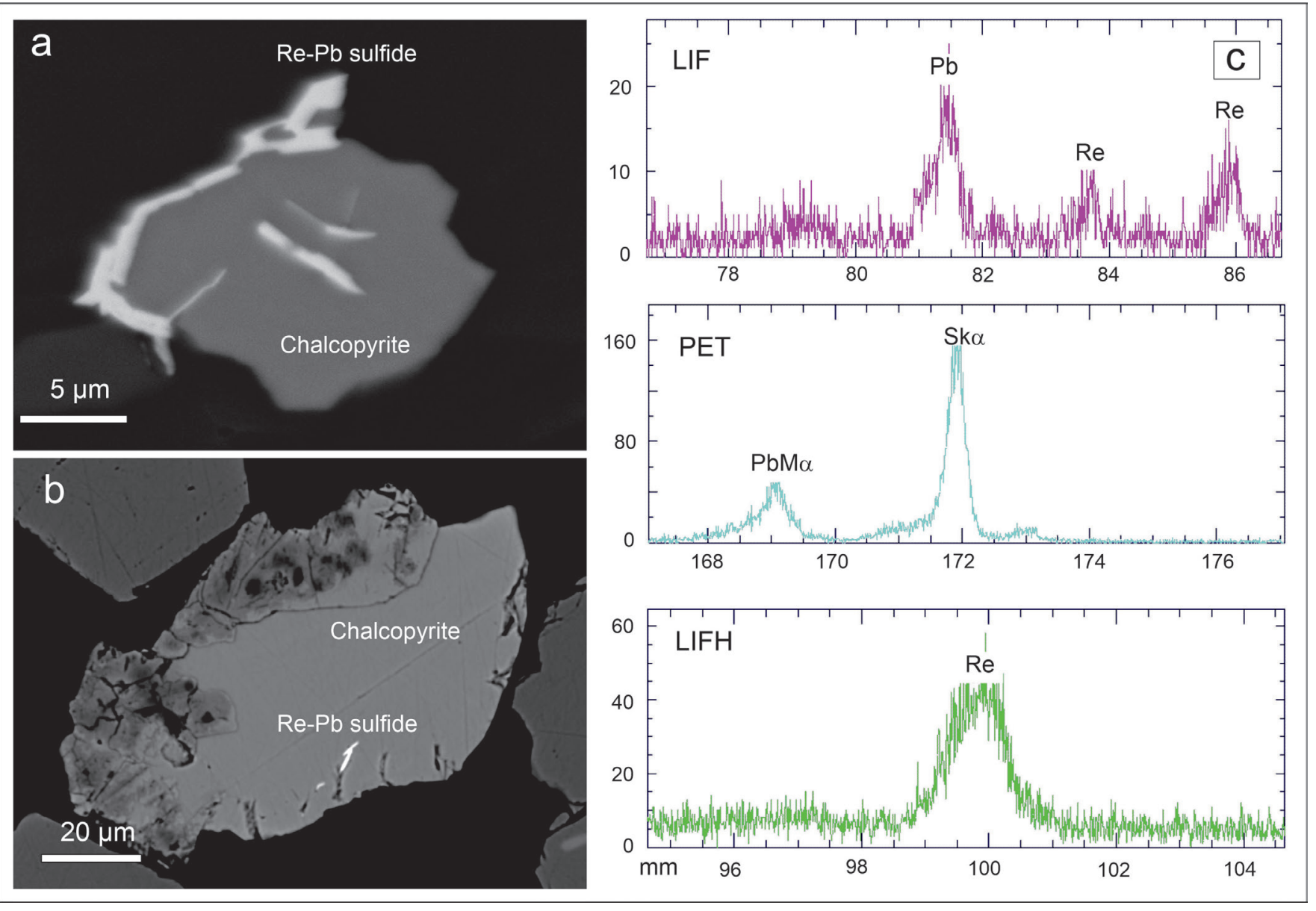

Figure 14. (a) Back-scatter electron images of Re-Pb sulfide attached to chalcopyrite, section P25; (b) Back-scatter electron image of Re-Pb-(Mo-Fe-Cu) sulfide enclosed by chalcopyrite, hydroseparation concentrate P25_50-75 $\mu \mathrm{m}$; (c) wave-length dispersive X-ray element scans of Pb, Re (LIF crystal), Pb and S (PET crystal) and Re (LIFH crystal) in Re-Pb-(Mo-Fe-Cu) sulfide of Figure $11 \mathrm{~b}$.

analysis of ore concentrates yielded $28-116 \mathrm{mg} / \mathrm{kg} \mathrm{Ag}$, $<1.4 \mathrm{mg} / \mathrm{kg}$ Au and $2.1-15.2 \% \mathrm{Cu}$. The stratiform deposits in the Brenntal area located $6.5 \mathrm{~km}$ WNW of the Haidbach deposit are hosted by chlorite and sericite-chlorite schist derived from basaltic metatuff (Kling et al., 1997; Brandner, 2020). These rocks are part of the Hollersbach Complex and thus in the same lithotectonic unit as the Haidbach ore (Pihapper nappe; Fig. 1, Appendix 1). However, ore mineralogy and trace elements differ significantly from Haidbach. The Brenntal ore is dominated by pyrite and chalcopyrite, followed by sphalerite and galena, while pentlandite and $\mathrm{Ni}-\mathrm{Co}$ sulpharsenides are missing. Chalcopyrite is low in $\mathrm{Cd}$ but elevated in $\mathrm{Ag}$ and $\mathrm{Sn}$ compared to Haidbach. Pyrite has 10 times lower Ni and Co concentrations and is almost free of As (Brandner, 2020).

The composition of sulfide minerals in the Haidbach mineralization may help to further elucidate the genesis of the deposit. Trace element analyses discriminate magmatic from hydrothermal chalcopyrite and pyrite (Duran et al., 2015, 2019; George et al., 2018) (Fig. 15). Therefore, we compare trace element compositions of Haidbach sulfides with those from other deposits hosted by Palaeozoic rocks in the central and eastern Tauern
Window (Melcher and Onuk, 2019a, b; Appendix 1). In the Se-Cd-Ni diagram, chalcopyrite data from Haidbach partly plot into the magmatic and partly into the hydrothermal fields, whereas all chalcopyrite analyses derived from other deposits in the Hollersbach and Peitingalm Complexes plot along the Se-Cd line due to low Ni concentrations (Fig. 15a). The considerable spread of the Haidbach data likely indicates metamorphic overprint of magmatic sulfides. Compared to chalcopyrite analysed in the Brenntal, Hochfeld and Sprinzgasse ores, chalcopyrite from Haidbach and Peitingalm (Fig. 1) is characterized by high $\mathrm{Cd} / \mathrm{Zn}$ ratios typical for high-temperature magmatic chalcopyrite (Fig. 15b). In a Co/Sb versus Se/As diagram (Duran et al., 2015), pyrite analyses from Haidbach plot into the magmatic field, discriminated by high $\mathrm{Co}$ and As concentrations (Fig. 16). The Hochfeld and Brenntal pyrites are more Se-rich and still occupy the magmatic field, whereas the Sprinzgasse deposit (Fig. 1) and mesothermal vein-type ores from Gastein (Radhausberg; Fig. 1) plot into the hydrothermal field. In conclusion, the Haidbach ore is the only deposit analysed in Palaeozoic host rocks in the Tauern Window showing a dominantly magmatic character in trace element chemistry of 


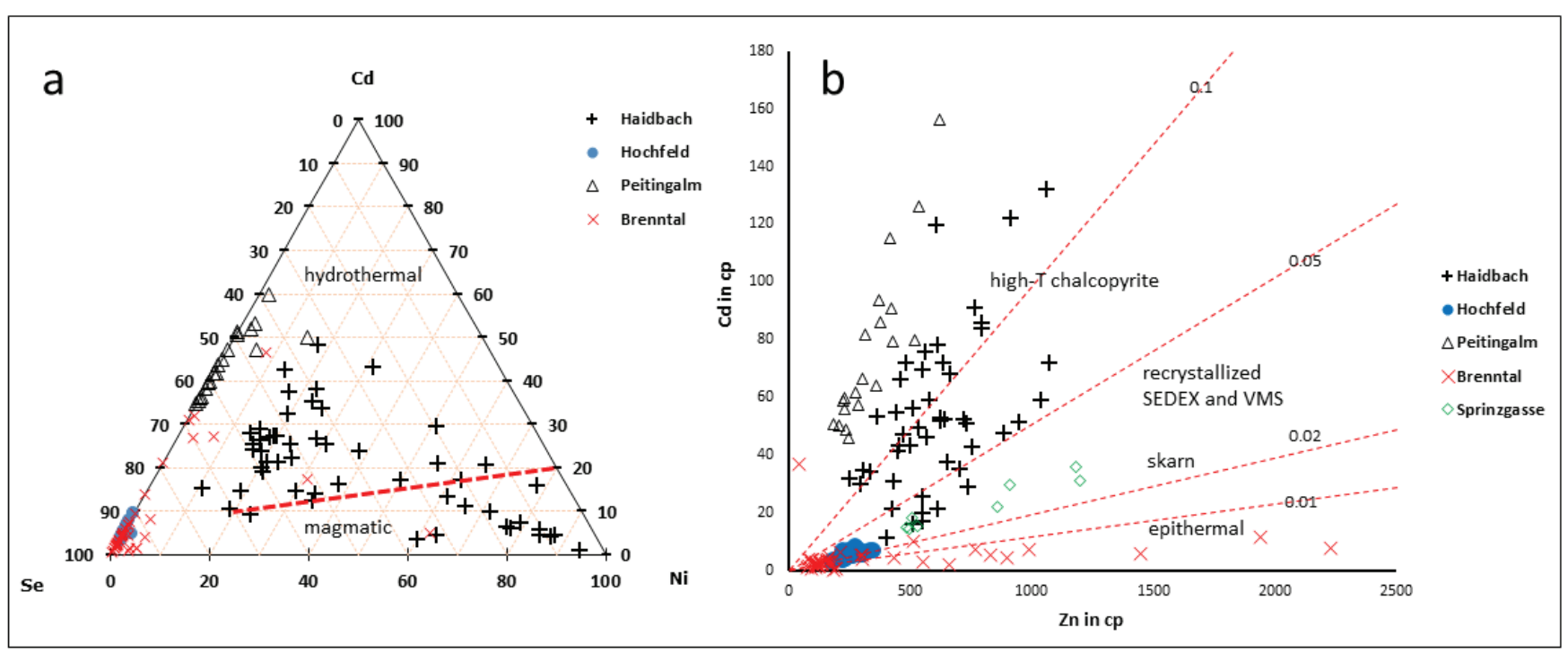

Figure 15. Discrimination of chalcopyrite using trace elements. (a) Cd-Se-Ni diagram (Duran et al., 2018) ; (b) Zn-Cd diagram illustrating a genetic subdivision proposed by George et al. (2018) and Duran et al. (2019).

chalcopyrite and pyrite. Other stratiform $\mathrm{Cu}$ - and Au-rich ores in the Palaeozoic Subpenninic units display dominantly hydrothermal characteristics.

\subsection{Comparison with orthomagmatic Cu-Ni-PGE deposits}

The Haidbach mineral assemblage resembles typical magmatic nickeliferous sulfide ore hosted by gabbro or ultramafic rocks, e.g. at Norilsk, Sudbury and Pechenga. $\mathrm{Pd}-(\mathrm{Pt})$ tellurides are frequently reported from metamorphosed sulfide deposits hosted by ultramafic-mafic rocks, such as Las Aguilas, Argentina (Gervilla et al., 1997; Mogessie et al., 2000), Eastern Desert, Egypt (Helmy, 2005), southwestern China (Song et al., 2004), central and northern Finland (e.g., Hitura, Keivitsa, Sakatti; Gervilla and Kojonen, 2002; Makkonen, 2015; Makkonen et al., 2017), but also in the Lusatian Block, Germany (Sandmann and Gutzmer, 2014) and others. Compositions of Co-Ni-Fe sulfarsenides at Las Aguilas and in the Yangliuping sulfide deposit, SW China, closely match the high-temperature ternary compositions at Haidbach, and $\mathrm{Pd}-\mathrm{Ni}$ bismuthotellurides range from merenskyite to palladian bismuthian melonite (Gervilla et al., 1997). At Yangliuping, testibiopalladite, sperrylite and Pd-melonite are the most common PGM (Song et al., 2004) and formed by exsolution from monosulfide solid solution upon cooling.

With few exceptions, PGE findings in general are related either to layered igneous complexes emplaced in continental crust, to ultramafic lava flows (komatiites), to flood basalt provinces or to mantle and lower crustal sections of ophiolite complexes. While the first three settings are missing in the European Alps, relics of ultramafic mantle and lower crustal rocks are locally preserved. The Alpine orogen in central Europe formed as a result of complex collision processes of the European plate with terranes and plates along the northern Gondwana margin during the Upper Cretaceous to Neogene. Subduction of oceanic crust led to obduction of incomplete ophiolite sequences and upper mantle rocks that are now exhumed in Penninic windows in the Eastern Alps. However, accumulation of chromian spinel and associated PGE did not take place in Mesozoic upper mantle and oceanic crustal rocks (Melcher et al., 2002). In contrast, some of the pre-Alpine (e.g. "Cadomian") ophiolites and oceanic mantle rocks are known to carry subeconomic concentrations of chromite and PGM, dominated by Ru-Os-Ir sulfides and sulfarsenides (Thalhammer et al., 1988, 1990; Melcher and Mali, 1998; Melcher, 2000; Malitch et al., 2001, 2003a,b). Geochemical studies suggest chromite formation in a supra-subduction zone setting during the Upper Proterozoic (Melcher et al., 2002; Melcher and Meisel, 2004).

The Ivrea Verbano Zone of northern Italy represents the second "hot spot" of PGM in the Alps, with chromitite containing Ru-Os-Ir-Rh-Pt sulfides (Finero complex: Ferrario and Garuti, 1990; Garuti et al., 1995), and Fe-Ni-Cu-(PGE) sulfide deposits associated with various intrusive units of the mafic magmatic complex (Ferrario et al., 1983; Garuti and Rinaldi, 1986, 1987; Garuti et al., 1986, 1990; Zaccarini et al., 2014). Various styles of $\mathrm{Ni}$-Cu sulfide ores have been reported from the Ivrea Verbano Zone (Zaccarini et al., 2014). The mineralogy of Fe-Ni-Cu sulfide deposits associated with pipe-like ultramafic bodies of amphibole and phlogopite peridotite and pyroxenite emplaced into the main gabbro unit closely resembles the Haidbach ore, with pyrrhotite, pentlandite and chalcopyrite as major, and cubanite, mackinawite, molybdenite, grafite and $\mathrm{Ni}$-Co sulfarsenides as minor phases in the ore. The ore is rich in PGE (whole-rock tenor up to $4.4 \mathrm{mg} / \mathrm{kg} \mathrm{Pd}+$ $\mathrm{Pt}, 2.3 \mathrm{mg} / \mathrm{kg} \mathrm{Au}$ ) and carries (Pd, Pt)-melonite, sperrylite, irarsite, $\mathrm{Ag}-\mathrm{Pb}$-Bi tellurides (e.g. hessite, altaite) and electrum. Thus, the pipe ore observed at several locations in 


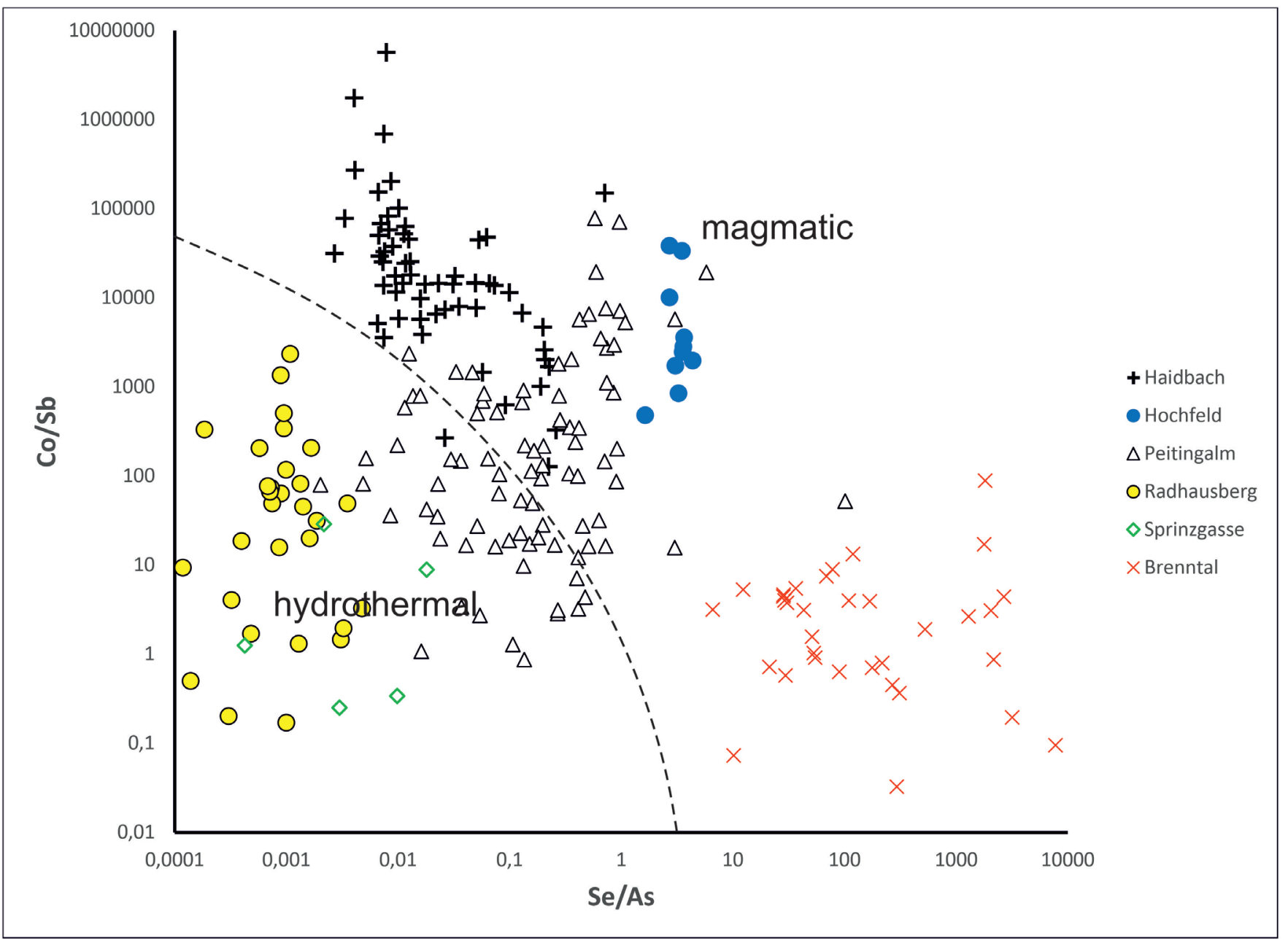

Figure 16. Pyrite discrimination using trace element ratios (Duran et al., 2015).

the Ivrea Verbano Complex is the closest match to the Haidbach $\mathrm{Ni}-\mathrm{Cu}-\mathrm{Co}-\mathrm{PGE}$ mineralization known from the Alps. These ores are all Pd and Pt dominated, with very low Os, Ir and Ru. Sperrylite and Pd bismuthotellurides are the dominant PGM with minor irarsite. It is interesting to note that Re sulfides were discovered in a polished section from the la Balma-Monte Capio sill (Zaccarini et al., 2014). The grains are small $(<3 \mu \mathrm{m})$ and were tentatively attributed to rheniite $\left[\operatorname{ReS}_{2}\right]$. The shape of one grain reported by Zaccarini et al. (2014) closely resembles tarkianite grains documented in the present study (Figs. 8b, 12). The rare mineral rheniite is triclinic and described as "mica-like" or "molybdenite-like" (Znamensky et al., 2005), which may apply to the second Re sulfide documented (Fig. 6b of Zaccarini et al., 2014). The presence of "rheniite" in the sill ore type was attributed to crustal contamination processes (Zaccarini et al., 2014).

\section{Summary and conclusions}

The Haidbach mineralization represents the only unequivocal primary orthomagmatic Cu-Ni-Co-PGE deposit in the Palaeozoic Subpenninic units of the central
Tauern Window. Massive sulfide ores are originally associated with pyroxenite and are now highly deformed and overprinted by polymetamorphic events (Variscan, Neoalpine). Relict high-temperature textures and minerals have partly been preserved. The ore consists of Ni-rich pyrrhotite, pentlandite (partly Co and Ag-rich), Co and As-rich pyrite and $\mathrm{Ni}-\mathrm{Cd}$-bearing chalcopyrite. Co-Ni-Fe sulfarsenides record temperatures (up to $600{ }^{\circ} \mathrm{C}$ ) that are higher than those estimated for the Neoalpine event $\left(<450^{\circ} \mathrm{C}\right)$. Trace element compositions of pyrite and chalcopyrite point to a magmatic high-temperature mineralization event. Exsolution of monosulfide and intermediate sulfide solid solution from silicate melt takes place at temperatures $<1100{ }^{\circ} \mathrm{C}$. It is unlikely that high-temperature chalcopyrite still retains its high-temperature trace element composition. However, the low abundance of sphalerite as the main Cd carrier in the Haidbach assemblage indicates elevated $\mathrm{Cd}$ concentrations in the sulfide melt that were partitioned into sphalerite and chalcopyrite upon cooling and remained in chalcopyrite during subsolidus equilibration processes. Sulfide ores at Haidbach carry significant concentrations of $\mathrm{Pd}, \mathrm{Pt}$ Re and $\mathrm{Au}$. 
PGM and Re sulfides crystallized from moderately PGE, Re and Te-rich silicate melt with PGE tenors of $2.6 \mathrm{mg} / \mathrm{kg} \mathrm{Pd}$ and $1.1 \mathrm{mg} / \mathrm{kg}$ Pt in $100 \%$ sulfide melt during magmatic cooling and subsequent polyphase metamorphic events under amphibolite facies (Variscan event?) and greenschist facies conditions (Neoalpine event). Pyrite formed at the expense of pyrrhotite, probably exsolving some of the precious metal phases such as tarkianite. The present mineralogy of the Haidbach ore is the result of a complex evolution including exsolution of a $\mathrm{Ni}$-Cu-Fe-rich sulfide melt from a pyroxenitic silicate melt, subsolidus processes forming discrete sulfide and trace minerals, and polyphase overprint during at least two metamorphic events, probably associated with metasomatic contributions from country rocks.

\section{Acknowledgements}

This publication is based on results of Sonja Schwabl's Master thesis (Schwabl, 2016) carried out at Leoben. We gratefully acknowledge the support of Monika Feichter, Heinz Mali, the members of the Schurfgemeinschaft Zinkwand (Hans Grill, Erich Maierhofer, Egon Mürzl, Karl Zechmann), Josef Seifriedsberger and Arthur Maurer during field work. Sabine Feuchter (sample preparation), Federica Zaccarini and Maik Zimmermann (Eugen F. Stumpfl Electron Microprobe Laboratory, Leoben) supported the analytical work at MUL. Dan Topa helped with high resolution imaging at the FEG electron microprobe, Natural History Museum, Vienna. We also thank Fritz Koller for helpful advice concerning the petrology of the Habach Group. LA-ICP-MS analytical work was supported by grant W07:710/2017/004 (GBA-Forschungspartnerschaft: Grundlagenorientierte Mineralrohstoffforschung) financed by the Federal Ministry of Agriculture, Regions and Tourism (Austria). The manuscript benefitted from reviews of Kari Kojonen and an anonymous reviewer. The support by editor Kurt Stüwe is greatly appreciated.

\section{References}

Aigner, F., 1938. Nickel- und Kupfererzvorkommen Haibach. Unpublished report, Archives of the Geologische Bundesanstalt Wien, $5 \mathrm{p}$.

Aiglsperger, T., Proenza, J.A., Zaccarini, F., Lewis, J.F., Garuti, G., Labrador, M., Longo, F., 2015. Platinum group minerals (PGM) in the Falcondo Ni-laterite deposit, Loma Caribe peridotite (Dominican Republic). Mineralium Deposita, 50/7, 105-123. http://dx.doi.org/10.1007/ s00126-014-0520-9

Barnes, S.-J., Lightfoot, P.C., 2005. Formation of magmatic nickel sulfide deposits and processes affecting their copper and platinum group element contents. Economic Geology 100th Anniversary volume, pp. 179-213.

Bokhary, S.N.H., Meisel, T.C., 2017. Method Development and Optimisation of Sodium Peroxide Sintering for Geological Samples. Geostandards and Geoanalytical Research, 41, 181-195. https://doi.org/10.1111/ ggr.12149
Brandner, P., 2020. Mineralogie und Spurenelement-Analyse des Reviers Brenntal im Tauernfenster, Salzburg. Unpublished Bachelor thesis, Montanuniversität Leoben, $86 \mathrm{p}$.

Cabri, L. J., Rowland, J.F., Laflamme, J.H.G., Stewart, J.M., 1979. Keithconnite, telluropalladinite and other Pd-Pt tellurides from the Stillwater complex, Montana. Canadian Mineralogist, 17, 589-594.

Dill, H.G., Klosa, D., Steyer, G., 2009. The "Donauplatin": source rock analysis and origin of a distal fluvial Au-PGE placer in Central Europe. Mineralogy and Petrology, 96/34, 141-161. https://doi.org/10.1007/s00710-009-0060-7

Duran, C.J., Barnes, S.-J., Corkery, J.T., 2015. Chalcophile and platinum-group element distribution in pyrites from the sulfide-rich pods of the Lac des lles Pd deposits, Western Ontario, Canada: Implications for post-cumulus re-equilibration of the ore and the use of pyrite compositions in exploration. Journal of Geochemical Exploration, 158, 223-242. http://dx.doi.org/10.1016/j. gexplo.2015.08.002

Duran, C.J., Dubé-Loubert, H., Pagé, P., Barnes, S.-J., Roy, M., Savard, D., Cave, B.J., Arguin, J.-P., Mansur, E.T., 2019. Applications of trace element chemistry of pyrite and chalcopyrite in glacial sediments to mineral exploration targeting: Example from the Churchill Province, northern Quebec, Canada. Journal of Geochemical Exploration, 196, 105-130. http://dx.doi.org/10.1016/j. gexplo.2018.10.006

Eichhorn, R., Höll, R., Jagoutz, E., Schärer, U., 1997. Dating scheelite stages: a strontium, neodymium, lead approach from the Felbertal tungsten deposit, Central Alps, Austria. Geochimica et Cosmochimica Acta, 61/23, 5005-5022. https://doi.org/10.1016/S0016-7037(97)00349-9

Ferrario, A., Garuti, G., 1990. Platinum-group mineral inclusions in chromitites of the Finero mafic-ultramafic complex (Ivrea-Zone, Italy). Mineralogy and Petrology, 41, 125-143. https://doi.org/10.1007/BF01168491

Ferrario, A., Garuti, G., Rossi, A., Sighinolfi, G.P., 1983. Petrographic and metallogenic outlines of the La Balma-M. Capio ultramafic-mafic body (Ivrea-Verbano Basic Complex, NW Italian Alps). In: Schneider, H.J. (ed.): Mineral deposits of the Alps and of the Alpine epoch in Europe. Society of Geology Applied to Mineral Deposits, Special Publication, 3, 28-40, Proceedings of the IV. ISMIDA 1981, Springer, Berlin.

Frank, W., Miller, Ch., Pestal, G., 1987. Geologische Karte der Republik Österreich 1:50 000. Blatt 152 Matrei in Osttirol. Geologische Bundesanstalt, Wien.

Frasl, G., 1958. Zur Seriengliederung der Schieferhülle in den mittleren Hohen Tauern. Jahrbuch der Geologischen Bundesanstalt, 101, 323-472.

Garuti, G., Rinaldi, R., 1986. Melonite-group and other tellurides from the Ivrea-Verbano Basic Complex, Western Italian Alps. Economic Geology, 81/5, 1213-1217. https://doi.org/10.2113/gsecongeo.81.5.1213

Garuti, G., Rinaldi, R., 1987. Further data on platinum-palladium minerals from the Ivrea-Verbano sulfide deposits. In: Prichard, H.M., Potts, H.P., Bowles, J.F.W. and Cribb, S.J. (eds.), Geo-Platinum 87. Elsevier, London, pp. 179. 
Garuti, G., Fiandri, P., Rossi, A., 1986. Sulfide composition and phase relations in the $\mathrm{Fe}-\mathrm{Ni}$-Cu ore deposits of the Ivrea-Verbano basic complex (Western Alps, Italy). Mineralium Deposita, 21/2, 22-34. https://doi.org/10.1007/ BF00204358

Garuti, G., Gazzotti, M., Torres-Ruiz, J., 1995. Iridium, rhodium and platinum sulfides in chromitites from the ultramafic massifs of Finero, Italy, and Ojén, Spain. Canadian Mineralogist, 33/3, 509-520.

Garuti, G., Naldrett, A.J., Ferrario, A., 1990. Platinum-group elements in magmatic sulfides from the Ivrea Verbano Zone: their control by sulfide assimilation and silicate fractionation. Economic Geology, 85/2, 328-336. https:// doi.org/10.2113/gsecongeo.85.2.328

George, L., Cook, N.J., Crowe, B.B.P., Ciobanu, C.L., 2018. Trace elements in hydrothermal chalcopyrite. Mineralogical Magazine, 82/1, 59-88. http://dx.doi. org/10.1180/minmag.2017.081.021

Genkin, A.D., Poplavko, E.M., Gorshhov, A.I., Tsepin, A.I., Sivtsov, A.V., 1994. New data on dzhezkazganite - rhenium-molybdenum-copper-lead sulfide - from the Dzhezkazgan deposit (Kazakhstan). Geology of Ore Deposits, 36/6, 481-489 (translation from Geol. Rudnykh Mestorozhdenii, 36, 536-544; in: Jambor, J.L., Puziewicz, J., Roberts, A.C., 1995. New mineral names. American Mineralogist, 80/11-12, 1328-1333.

Gervilla, F., Kojonen, K., 2002. The platinum-group minerals in the upper section of the Keivitsansarvi Ni-Cu-PGE deposit, northern Finland. Canadian Mineralogist, 40, 377-394. http://dx.doi.org/10.2113/gscanmin.40.2.377

Gervilla, F., Sánchez-Anguita, S., Acevedo, R.D., Fenoll Hach-Ali, P., Paniagua, A., 1997. Platinum-group element sulfarsenides and Pd bismuthotellurides in the metamorphosed Ni-Cu deposit at Las Aguilas (Province of San Luis, Argentina). Mineralogical Magazine, 61/12, 861-877.

Gross, P., Pleuger, J., Handy, M.R., Germer, M., John, T., 2020. Evolving temperature field in a fossil subduction channel during the transition from subduction to collision (Tauern Window, Eastern Alps). Journal of Metamorphic Geology. http://dx.doi.org/10.1111/jmg.12572 Grundmann, G., Brandstätter, F., Seemann, R., Koller, F., 1990. Gold-, Bismut- und Tellurmineralisationen der Lagerstätte Hochfeld, Untersulzbachtal (Tauernfenster). Mitteilungen der Österreichischen Mineralogischen Gesellschaft, 135, 31-32.

Heinisch, H., Pestal, G., Reitner, J.M., Stingl, V., 2003. Geologische Karte der Republik Österreich 1: 50 000. Blatt 122 Kitzbühel. Geologische Bundesanstalt, Wien.

Heinisch, H., Pestal, G., Reitner, J.M., 2015. Erläuterungen zu Blatt 122 Kitzbühel. Geologische Karte der Republik Österreich 1:50 000. Geologische Bundesanstalt, Wien, $301 \mathrm{p}$.

Helmy, H.M., 2005. Melonite group minerals and other tellurides from three $\mathrm{Cu}-\mathrm{Ni}-\mathrm{PGE}$ prospects, Eastern Desert, Egypt. Ore Geology Reviews, 26/3-4, 305-324. http://dx.doi.org/10.1016/j.oregeorev.2005.04.001

Helmy, H.M., Ballhaus, C., Berndt, J., Bockrath, C., Wohlgemuth-Ueberwasser, C., 2007. Formation of Pt, Pd and
Ni tellurides: experiments in sulfide-telluride systems. Contributions to Mineralogy and Petrology, 153/5, 577591. http://dx.doi.org/10.1007/s00410-006-0163-7

Helmy, H. M., Ballhaus, C., Fonseca, R. O. C., Nagel, T. J., 2013. Fractionation of platinum, palladium, nickel, and copper in sulfide-arsenide systems at magmatic temperature. Contributions to Mineralogy and Petrology, 166/6, 17251737. http://dx.doi.org/10.1007/s00410-013-0951-9

Johan, Z., Ohnenstetter, W., Fischer, J., 1990. Platinum-group minerals from the Durance river alluvium, France. Mineralogy and Petrology, 42/1-4, 287-306. https://doi.org/10.1007/BF01162696

Klemm, D., 1965. Synthese und Analysen in den Dreiecksdiagrammen FeAsS-CoAsS-NiAsS und $\mathrm{FeS}_{2}-\mathrm{CoS}_{2}-\mathrm{NiS}_{2}$. Neues Jahrbuch für Mineralogie, 103, 205-255.

Kling, M., Loth, G., Kupferschmied, M., Lewandowski, K., 1997. Die Kupferlagerstätte Brenntal (Tauernfenster): Bergbaugeschichte, Geologie, Erzmineralogie und Flüssigkeitseinschluß-Untersuchungen. Archiv für Lagerstättenforschung der Geologischen Bundesanstalt, 20, 5-13. https://www.zobodat.at/pdf/ArchivLagerstGBA_20_0005-0013.pdf

Kojonen, K.K., Roberts, A.C., Isomäki, O.-P., Knauf, V.V., Johanson, B., Pakkanen, L., 2004. Tarkianite, (Cu,Fe) $(\mathrm{Re}, \mathrm{Mo})_{4} \mathrm{~S}_{8}$ a new mineral species from the Hitura mine, Nivala, Finland. Canadian Mineralogist, 42/2, 539-544. http://dx.doi.org/10.2113/gscanmin.42.2.539

Kozlik, M., Gerdes, A., Raith, J.G., 2016a. Strontium isotope systematics of scheelite and apatite from the Felbertal tungsten deposit, Austria - results of in-situ LA-MCICP-MS analysis. Mineralogy and Petrology, 110/1, 11-27. https://doi.org/10.1007/s00710-015-0416-0

Kozlik, M., Raith, J.G., Gerdes, A., 2016b. U-Pb, Lu-Hf and trace element characteristics of zircon from the Felbertal scheelite deposit (Austria): New constraints on timing and source of W mineralization. Chemical Geology, 421/1, 112-126. https://doi.org/10.1016/j.chemgeo.2015.11.018

Lerch, H., Lewandowski, K., Seemann, R., 2009. Bergbau im Untersulzbachtal. Zukunftskollegium Nationalpark Hohe Tauern Neukirchen, 2. Auflage, 288 p.

Makkonen, H.V., 2015. Nickel Deposits of the $1.88 \mathrm{Ga}$ Kotalahti and Vammala Belts. In: O'Brien, Lahtinen et al. (ed.) 2015 - Mineral Deposits of Finland, 253-290. http:// dx.doi.org/10.1016/B978-0-12-410438-9.00010-8

Makkonen, H.V., Halkoaho, T., Konnunaho, J., Rasilainen, K., Kontinen, A., Eilu, P., 2017. Ni-(Cu-PGE) deposits in Finland - Geology and exploration potential. Ore Geology Reviews, 90, 667-696. http://dx.doi.org/10.1016/j. oregeorev.2017.06.008

Malitch, K.N., Junk, S.A., Thalhammer, O.A.R., Melcher, F., Knauf, V.V., Pernicka, E., Stumpfl, E.F., 2003a. Laurite and ruarsite from podiform chromitites at Kraubath and Hochgrössen, Austria: new insights from osmium isotopes. Canadian Mineralogist, 41/2, 331-352. http:// dx.doi.org/10.2113/gscanmin.41.2.331

Malitch, K.N., Melcher, F., Mühlhans, J., 2001. Palladium and gold mineralization in podiform chromitite at 
Kraubath, Austria. Mineralogy and Petrology, 73/4, 247277. http://dx.doi.org/10.1007/s007100170002

Malitch, K.N., Thalhammer, O.A.R., Knauf, V.V., Melcher, F., 2003b. Diversity of platinum-group mineral assemblages in an Eastern Alpine ophiolite: a case study of banded and podiform chromitite from the Kraubath ultramafic massif, Austria. Mineralium Deposita, 38/3, 282-297. http://dx.doi.org/10.1007/s00126-002-0308-1

Meisel, T., Schöner, N., Paliulionyte, V., Kahr, E. 2002. Determination of rare earth elements, $\mathrm{Y}, \mathrm{Th}, \mathrm{Zr}, \mathrm{Hf}, \mathrm{Nb}$ and $\mathrm{Ta}$ in geological reference materials G-2, G-3, SCo-1 and WGB-1 by sodium peroxide sintering and inductively coupled plasma-mass spectrometry. Geostandards Newsletter: The Journal of Geostandards and Geoanalysis, 26, 53-61. https://doi.org/10.1111/j.1751-908X.2002.tb00623.x

Melcher, F., 2000. Base metal - platinum group element sulfides from the Urals and the Eastern Alps: characterization and significance for mineral systematics. Mineralogy and Petrology 68/1-3, 177-211. http://dx.doi. org/10.1007/s007100050009

Melcher, F., Mali, H., 1998. Platingruppenminerale in Chromititen von Kraubath. Mitteilungen der Abteilung Mineralogie des Landesmuseum Joanneum, 62/63, 39-48.

Melcher, F., Meisel, T., 2004. A metamorphosed Early Cambrian crust - mantle transition in the Eastern Alps, Austria. Journal of Petrology, 45/8, 1689-1723. http://dx. doi.org/10.1093/petrology/egh030

Melcher, F., Meisel, T., Puhl, J., Koller, F., 2002. Petrogenesis and geotectonic setting of ultramafic rocks in the Eastern Alps: constraints from geochemistry. Lithos, 65/1-2, 69-112. http://dx.doi.org/10.1016/S0024-4937(02)00161-5 Melcher, F., Onuk, P., 2019a. Potential of Critical High-technology Metals in Eastern Alpine Base Metal Sulfide Ores. Berg- und Hüttenmännische Monatshefte, 164/2, 71-76. https://doi.org/10.1007/s00501-018-0818-5

Melcher, F., Onuk, P., 2019b. Laser Ablation-ICP-MS Bestimmung von Spurenelementen in Eisen- und Kupfersulfiden österreichischer Lagerstätten. Final Report of Project Wo7:710/2017/004, Projekte zur Mineralrohstoffforschung, 80 p., Geologische Bundesanstalt, Wien. Melcher, F., Onuk, P., Schwabl, S., Zimmermann, M., Aiglsperger, T., 2019. Rhenium sulfides and platinumgroup minerals at Haidbach/Pinzgau - recent results. Mitteilungen der Österreichischen Mineralogischen Gesellschaft, 165, 64.

Melcher, F., Schwabl, S., Aiglsperger, T., Proenza, J.A., 2017. Orthomagmatic Ni-Cu-PGE mineralization in the Eastern Alps? Evidence from Haidbach, Tauern Window, Austria. Proceedings of the 14th Biennial SGA Meeting, 20-23 August 2017, Québec City, Canada, pp 487-490.

Mogessie, A., Hauzenberger, Ch. A., Hoinkes, G., Felfernig, A., Stumpfl, E.F., Bjerg, E.A., Kostadinoff, J., 2000. Genesis of platinum-group minerals in the Las Aguilas mafic-ultramafic rocks, San Luis Province, Argentina: textural, chemical and mineralogical evidence. Mineralogy and Petrology, 68/1-3, 85-114. https://doi.org/10.1007/ s007100050005
Niedermayr, G., Schroll, E., 1983. The tungsten distribution in rocks of the Western Hohe Tauern. In: Schneider, H.-J. (ed.), Mineral deposits of the Alps and of the Alpine epoch in Europe. Society of Geology Applied to Mineral Deposits, Special Publication, 3, pp. 240-248, Proceedings of the IV. ISMIDA 1981, Springer.

Oberthür, T., Melcher, F., Goldmann, S., Wotruba, H., Gerdes, A., Dijkstra, A., Dale, C., 2016. Mineralogy and mineral chemistry of detrital heavy minerals from the Rhine River in Germany as evidence to their provenance, sedimentary and depositional history: focus on platinum-group minerals and remarks on cassiterite, columbite-group minerals, and uraninite. International Journal of Earth Sciences, 105/2, 637-657. http://dx.doi. org/10.1007/s00531-015-1181-3

Onuk, P., Melcher, F., Mertz-Kraus, R., Gäbler, H.-E., Goldmann, S., 2017. Development of a matrix-matched sphalerite reference material (MUL-ZnS-1) for calibration of in situ trace element measurements by laser ablation inductively coupled plasma mass spectrometry. Geostandards and Geoanalytical Research, 41/2, 263-272. http://dx.doi.org/10.1111/ggr.12154

Paar, W.H., 1994. Erze und Lagerstätten. In: Mineral \& Erz in den Hohen Tauern, Naturhistorisches Museum Wien, 89-102.

Paar, W.H., 2000. Montangeologie des Tauerngoldes. In: W. Günther, W.H. Paar (eds.), Schatzkammer Hohe Tauern - 2000 Jahre Goldbergbau. Pustet, München, pp. 302-366.

Paton, C., Hellstrom, J., Paul, B., Woodhead, J., Hergt, J., 2011. Iolite. Freeware for the visualisation and processing of mass spectrometric data. Journal of Analytical Atomic Spectrometry, 26/12, 2508-2518. https://doi. org/10.1039/c1ja10172b

Pestal, G., Hejl, E., Braunstingl, R., Schuster, R., 2009. Erläuterungen Geologische Karte von Salzburg 1:200,000. Land Salzburg \& Geologische Bundesanstalt, Wien, pp. 1-162.

Petrakakis, K., 1977. Zur Geologie des Stubachtal Ultramafitit-Komplexes. Mitteilungen der Gesellschaft der Geologie- und Bergbaustudenten Wien, 24, 47-57.

Petrakakis, K., 1978. Der Stubachtal-Ultramafitit-Komplex (Salzburg, Österreich). Tschermaks mineralogische und petrographische Mitteilungen, 25/1, 1-32. https:// doi.org/10.1007/BF01082201

Raith, J.G., Stein, H.J., 2006. Variscan ore formation and metamorphism at the Felbertal scheelite deposit (Austria): constraining tungsten mineralisation from Re-Os dating of molybdenite. Contributions to Mineralogy and Petrology, 152/4, 505-521. https://doi. org/10.1007/s00410-006-0118-z

Raith, J.G., Gerdes, A., Cornell, D.H., 2011. In situ U-Pb dating of scheelite: constraints on the age and genesis of the Felbertal tungsten deposit. Mineralogical Magazine, 75/3, 1690.

Reitsch, A., 1911. Die Nickel- und Kupfererzlagerstätten von Mittersill. Unpublished report, Archive Geologische Bundesanstalt, Wien, $12 \mathrm{p}$. 
Rudashevsky, N.S., Lupal, S.D., Rudashevsky V.N., 2001. The hydraulic classifier. Russia patent N 2165300, Patent Cooperation Treaty PCT/RU01/00123 (Moscow: 20 April 2001; 10 May 2001) (in Russian and English)

Rudashevsky, N.S., Garuti, G., Andersen, J.C., Kretser, Yu. L., Rudashevsky, V.N., Zaccarini, F., 2002. Separation of accessory minerals from rocks and ores by hydroseparation (HS) technology: method and application to CHR-2 chromitite, Niquelândia intrusion, Brazil. Transactions of the Institution of Mining and Metallurgy, 111, B87-B94. https://doi.org/10.1179/aes.2002.111.1.87

Sandmann, D., Gutzmer, J., 2014. Nature and distribution of PGE mineralization in gabbroic rocks of the Lusatian Block, Saxony, Germany. Zeitschrift der Deutschen Gesellschaft für Geowissenschaften, 166, 35-53. https:// doi.org/10.1127/1860-1804/2014/0083

Schedl, A., Mauracher, J., Atzenhofer, B., Lipiarski, P., Rabeder, J., 2001. Systematische Erhebung von Bergbauen und Bergbauhalden mineralischer Rohstoffe im Bundesgebiet („Bergbau-Haldenkataster") - Bundesland Salzburg. Jahresendbericht Projekt Ü-LG-040/1999, Geologische Bundesanstalt, Wien, $130 \mathrm{p}$.

Schmid, S.M., Scharf, A., Handy, M.R., Rosenberg C.L., 2013. The Tauern Window (Eastern Alps, Austria): a new tectonic map, with cross-sections and a tectonometamorphic synthesis. Swiss Journal of Geosciences, 106/1, 1-32. http://dx.doi.org/10.1007/s00015-013-0123-y

Schuster, R., Koller, F., Höck, V., Hoinkes, G., Bousquet, R., 2004. Explanatory notes to the map: Metamorphic structure of the Alps - Metamorphic evolution of the Eastern Alps. Mitteilungen der Österreichischen Mineralogischen Gesellschaft, 149, 175-199.

Schwabl, S., 2016. Das PGE-führende Ni-Cu-Co Vorkommen im Haidbachgraben bei Mittersill. Master thesis, Montanuniversität Leoben, Austria, 92 p. https://pure.unileoben.ac.at/portal/files/1876599/ AC13289620n01vt.pdf

Schwabl, S., Melcher, F., Grill, H., 2015. First occurrence of platinum-group minerals in Salzburg: The Haidbachgraben Cu-Ni-Co deposit, Pinzgau. Mitteilungen der Österreichischen Mineralogischen Gesellschaft, 161, 117.

Schwabl, S., Melcher, F., Grill, H., 2016. Platinum-group element-bearing copper-nickel-cobalt mineralization in the Habach Group, Tauern Window, Salzburg. In: Ortner, H. (ed.), Abstract Volume of GeoTirol 2016 - Annual Meeting of DGGV and PANGEO Austria, 25.-28. September 2016, Innsbruck.

Seemann, R., Brandstätter, F., 1987. Altaitführende Erzparagenesen aus dem Blauwandstollen, Untersulzbachtal, Salzburg. Annalen des Naturhistorischen Museums, Wien 89A, 1-13.

Seemann, R., Koller, F., Grundmann, G., Brandstätter, F., Hejl, E., 1993. Die Kupferlagerstätte Hochfeld - ein Teilprofil der Habachformation im Untersulzbachtal (Salzburg). Abhandlungen der Geologischen Bundesanstalt Wien, 49, 49-66.

Seifriedsberger, J., 2015. Haidbach - Bergbau an der Gaiswand im Felbertal. Bramberger Montanhefte, 14, 151 p.
Song, X.-Y., Zhou, M.-F., Cao, Z.-M., 2004. Genetic relationships between base-metal sulfides and platinum-group minerals in the Yangliuping Ni-Cu-(PGE) sulfide deposit, southwestern China. Canadian Mineralogist, 42/2, 469483. https://doi.org/10.2113/gscanmin.42.2.469

Stalder, H. A., Wagner, A., Graeser, S., Stuker, P., 1998. Mineralienlexikon der Schweiz. Wepf, Basel, 380 p.

Thalhammer, O.A.R., Stumpfl, E.F., 1988. Platinum-group minerals from Hochgrössen ultramafic massif, Styria: first reported occurrence of PGM in Austria. Transactions of the Institution of Mining and Metallurgy (Section B: Applied Earth Sciences), 97, B77-82

Thalhammer, O.A.R., Prochaska, W., Mühlhans, H.W., 1990. Solid inclusions in chrome-spinels and platinum-group element concentrations from the Hochgrössen and Kraubath ultramafic massifs (Austria). Contributions to Mineralogy and Petrology, 105/1, 66-80. https://doi. org/10.1007/BF00320967

Weber, L. (ed.), 1997. Handbuch der Lagerstätten der Erze, Industrieminerale und Energierohstoffe Österreichs. Erläuterungen zur Metallogenetischen Karte von Österreich 1:500 000 unter Einbeziehung der Industrieminerale und Energierohstoffe. Archiv für Lagerstättenforschung der Geologischen Bundesanstalt, 19, 1-393.

Weber, L., Lipiarski, P. (eds.), 2020: IRIS Online. Interaktives Rohstoff Informations System. Geologische Bundesanstalt, Wien. https://geolba.maps.arcgis.com/ apps/webappviewer/index.html?id=ef8095943a714d 7893d41f02ec9c156d (Accessed on 09 December 2020)

Wilson, S. A., Ridley, W. I., Koenig, A. E., 2002. Development of sulfide calibration standards for the laser ablation inductively-coupled plasma mass spectrometry technique. Journal of Analytical Atomic Spectrometry, 17/4, 406-409. http://dx.doi.org/10.1039/B108787H

Zaccarini, F., Garuti, G., Fiorentini, M.L., Locmelis, M., Kollegger, P., Thalhammer, O.A.R., 2014. Mineralogical hosts of platinum group elements (PGE) and rhenium in the magmatic Ni-Fe-Cu sulfide deposits of the Ivrea-Verbano Zone (Italy): An electron microprobe study. Neues Jahrbuch für Mineralogie - Abhandlungen: Journal of Mineralogy and Geochemistry, 191/2, 169-187. http:// dx.doi.org/10.1127/0077-7757/2014/0255

Znamensky, V.S., Korzhinsky, M.A., Steinberg, G.S., Trachenko, S.I., Yakushev, A.I., Laputina, I.P., Bryzgalov, I.A., Samotoin, N.D., Magazina, L.O., Kuzmina, O.V., Organova, N.I., Rassulov, V.A., Chaplygin, I.V., 2005. Rheniite, $\operatorname{ReS}_{2}$, the natural rhenium disulfide from fumaroles of of Kudryavy volcano, Iturup Island, Kurile Islands. Zapiski Vserossiyskogo Mineralogicheskogo Obshchestva (Proceedings of the Russian Mineralogical Society), 134(5), 32-40 (Russian with English abstract).

Received: 30.6.2020

Accepted: 5.1.2021

Editorial Handling: Kurt Stüwe 